\title{
A model of sulphur solubility for hydrous mafic melts: application to the determination of magmatic fluid compositions of Italian volcanoes
}

\author{
Bruno Scaillet and Michel Pichavant \\ ISTO-CNRS, UMR 6613, Orléans, France
}

\begin{abstract}
We present an empirical model of sulphur solubility that allows us to calculate $f \mathrm{~S}_{2}$ if $P, T, f \mathrm{O}_{2}$ and the melt composition, including $\mathrm{H}_{2} \mathrm{O}$ and $\mathrm{S}$, are known. The model is calibrated against three main experimental data bases consisting in both dry and hydrous silicate melts. Its prime goal is to calculate the $f \mathrm{~S}_{2}$ of hydrous basalts that currently lack experimental constraints of their sulphur solubility behaviour. Application of the model to Stromboli, Vesuvius, Vulcano and Etna eruptive products shows that the primitive magmas found at these volcanoes record $f \mathrm{~S}_{2}$ in the range 0.1-1 bar. In contrast, at all volcanoes the magmatic evolution is marked by dramatic variations in $f \mathrm{~S}_{2}$ that spreads over up to 9 orders of magnitude. The $f \mathrm{~S}_{2}$ can either increase during differentiation or decrease during decompression to shallow reservoirs, and seems to be related to closed versus open conduit conditions, respectively. The calculated $f \mathrm{~S}_{2}$ shows that the Italian magmas are undersaturated in a FeS melt, except during closed conduit conditions, in which case differentiation may eventually reach conditions of sulphide melt saturation. The knowledge of $f \mathrm{~S}_{2}, f \mathrm{O}_{2}$ and $f \mathrm{H}_{2} \mathrm{O}$ allows us to calculate the fluid phase composition coexisting with magmas at depth in the C-O-H-S system. Calculated fluids show a wide range in composition, with $\mathrm{CO}_{2}$ mole fractions of up to 0.97. Except at shallow levels, the fluid phase is generally dominated by $\mathrm{CO}_{2}$ and $\mathrm{H}_{2} \mathrm{O}$ species, the mole fractions of $\mathrm{SO}_{2}$ and $\mathrm{H}_{2} \mathrm{~S}$ rarely exceeding 0.05 each. The comparison between calculated fluid compositions and volcanic gases shows that such an approach should provide constraints on both the depth and mode of degassing, as well as on the amount of free fluid in magma reservoirs. Under the assumption of a single step separation of the gas phase in a closed-system condition, the application to Stromboli and Etna suggests that the main reservoirs feeding the eruptions and persistent volcanic plumes at these volcanoes might contain as much as $5 \mathrm{wt} \%$ of a free fluid phase. Consideration of the magma budget needed to balance the amounts of volatiles emitted in the light of these results shows that the amount of nonerupted magma could be overestimated by as much as one order of magnitude.
\end{abstract}

Key words sulphur - hydrous basalts - volcanic gas - Italy

\section{Introduction}

The determination of the composition of the fluids that coexist with magmas at depth requires

Mailing address: Dr. Bruno Scaillet, ISTO-CNRS, UMR 6613, 1A Rue de la Férollerie, 45071 Orléans cedex 02, France; e-mail: bscaille@cnrs-orleans.fr
1) a good definition of the magma pre-eruptive conditions $\left(P, T, f \mathrm{O}_{2}, f \mathrm{~S}_{2}, f \mathrm{H}_{2} \mathrm{O}\right)$ and 2) solubility models for the main volatile species. The combination of these two sets of information allows us to calculate the fluid composition through the consideration of fluid-melt equilibria (e.g., Scaillet and Evans, 1999). For any volatile species dissolved in a silicate melt that is saturated in a fluid, equilibrium conditions demand that the fugacity $f_{i}$ of species $i$ in the melt equals its fugacity in the fluid. For water we have therefore

$$
f \mathrm{H}_{2} \mathrm{O}_{\text {melt }}=f \mathrm{H}_{2} \mathrm{O}_{\text {fluid }} \text {. }
$$


The relationships between fugacity (or activity) and concentration in silicate melts have been established mainly for $\mathrm{H}_{2} \mathrm{O}$ and $\mathrm{CO}_{2}$ for a wide range of melt compositions (e.g., Dixon et al., 1995; Papale, 1997; Zhang, 1999). Once the fugacity of a given volatile species has been determined, its partial pressure, $P_{i}$, can be determined via the simple eq. (1.2)

$$
P_{i}=\frac{f_{i}}{\gamma_{i}}
$$

where $\gamma_{i}$ is the fugacity coefficient of species $i$ in the fluid.

In the system $\mathrm{C}-\mathrm{O}-\mathrm{H}$, the other main species to be considered is $\mathrm{CO}_{2}$, except if $f \mathrm{O}_{2}$ is significantly below FMQ, in which case reduced species such as $\mathrm{H}_{2}, \mathrm{CO}$, and $\mathrm{CH}_{4}$ can be present as well (see Holloway, 1977). Therefore, considering that $\mathrm{H}_{2} \mathrm{O}$ and $\mathrm{CO}_{2}$ are the main volatile species in the fluid, we have the following equations:

$$
\begin{gathered}
P_{\mathrm{H}_{2} \mathrm{O}}=\frac{f_{\mathrm{H}_{2} \mathrm{O}}}{\gamma_{\mathrm{H}_{2} \mathrm{O}}} \\
P_{\mathrm{CO}_{2}}=\frac{f_{\mathrm{CO}_{2}}}{\gamma_{\mathrm{CO}_{2}}} .
\end{gathered}
$$

Since the fluid can be treated as a binary $\mathrm{H}_{2} \mathrm{O}$ $\mathrm{CO}_{2}$ system, we have also the constraint, $X_{i}$ being the mole fraction of species $i$ in the fluid

$$
X_{\mathrm{H}_{2} \mathrm{O}}+X_{\mathrm{CO}_{2}}=1 \text {. }
$$

Recalling that $P_{i}=X_{i} P_{\text {fluid }}$, eqs. (1.3) to (1.5) can be solved simultaneously to calculate both $P_{\mathrm{H}_{2} \mathrm{O}}$ and $P_{\mathrm{CO}_{2}}$ and thus $P_{\text {fluid }}$ since by definition

$$
P_{\text {fluid }}=\Sigma P_{i} \text {. }
$$

What is calculated through this approach is thus the pressure at which the melt becomes saturated in a fluid phase and the composition of this fluid. This method offers thus the possibility to constrain both the minimum pressure of magma reservoir and the fluid composition that is likely to escape this reservoir during an eruptive process. Obviously those two information are of considerable interest for the assessment of volcanic hazards. This approach was first applied using modern solubility models for $\mathrm{H}_{2} \mathrm{O}$ and $\mathrm{CO}_{2}$ by Anderson et al (1989) to the Bishop tuff eruption. Since then, several petrological studies have estimated the pressure depth at which magmas become fluid-saturated, assuming that the fluid phase is a binary $\mathrm{H}_{2} \mathrm{O}-\mathrm{CO}_{2}$ mixture (e.g., Roggensack et al., 1997).

Most arc magmas are, however, notoriously rich in sulphur. Over the last 15 years, several melt inclusions studies have shown that the preeruptive melt sulphur content of arc basalts is equal to, or even higher than, the amount of dissolved $\mathrm{CO}_{2}$ (e.g., Roggensack et al., 1997; Marianelli et al., 1995, 1999). This shows that sulphur bearing volatile species must be incorporated into the above approach for a more complete description of fluid-melt equilibria. The nature and proportion of S-bearing species, mostly $\mathrm{H}_{2} \mathrm{~S}$ and $\mathrm{SO}_{2}$, strongly depend on $\mathrm{fO}_{2}$, as for C-bearing species (see Holloway, 1977; Symonds et al., 1994). Unlike C-species, however, the redox range in which the $\mathrm{H}_{2} \mathrm{~S} / \mathrm{SO}_{2}$ ratio varies is exactly within the redox range recorded by most arc-magmas (i.e. NNO to $\mathrm{NNO}+2$ ). This $\mathrm{fO}_{2}$ sensitivity introduces an additional complication in the approach outlined above, since the role of $f \mathrm{O}_{2}$ on volatile speciation must be explicitly taken into account. The calculation of the pressure for fluid saturation of a magma saturated in a C-O-H-S fluid at an $\mathrm{fO}_{2}$ equal to or higher than $\mathrm{NNO}$ will require to solve the following equation:

$$
P_{\text {fluid }}=P_{\mathrm{H}_{2} \mathrm{O}}+P_{\mathrm{CO}_{2}}+P_{\mathrm{SO}_{2}}+P_{\mathrm{H}_{2} \mathrm{~S}}
$$

if the contribution of $\mathrm{CO}, \mathrm{CH}_{4}, \mathrm{H}_{2}, \mathrm{~S}_{2}$, and $\mathrm{O}_{2}$ partial pressures are ignored, which is a valid approximation under the redox conditions considered here $\left(f \mathrm{O}_{2}>\mathrm{NNO}\right)$. The $\mathrm{SO}_{2}$ and $\mathrm{H}_{2} \mathrm{~S}$ species abundances are controlled by the following equilibria:

$$
\begin{aligned}
& \frac{1}{2} \mathrm{~S}_{2}+\mathrm{O}_{2} \leftrightarrow \mathrm{SO}_{2} \\
& \frac{1}{2} \mathrm{~S}_{2}+\mathrm{H}_{2} \leftrightarrow \mathrm{H}_{2} \mathrm{~S}
\end{aligned}
$$

which show that what is needed to calculate $S$ bearing species fugacities is $f \mathrm{~S}_{2}$ or one over the three S-bearing species fugacities (assuming that both $f \mathrm{O}_{2}$ and $f \mathrm{H}_{2}$ are known, which are two 
quantities generally known or obtainable if the pre-eruptive conditions are determined in magmas).

The preceding section shows that there is a need for a solubility model for $\mathrm{S}$ in silicate melts. Up to recently, there was only one such a model (Wallace and Carmichael, 1992) which was calibrated for dry basalts and $f \mathrm{O}_{2}$ below NNO, using mostly the experimental data of Haughton et al. (1974). Clemente et al . (2004) have developed both a thermodynamic and an empirical sulphur solubility model for hydrous rhyolitic compositions. In the intermediate composition range, that is between basalt and rhyolite, only a few studies have been carried out at one bar (e.g., Katsura and Nagashima, 1974) and even fewer at high pressure (Carroll and Rutherford, 1987; Luhr, 1990; Carroll and Webster, 1994). Of the work done at high pressure, only that of Luhr (1990) provides sulphur solubility data obtained under known $f \mathrm{~S}_{2}$ estimated from either Fe-FeS equilibria or equilibrium assemblages involving anhydrite. Clearly, it is this mid-compositional range of hydrous mafic to intermediate magmas that still lacks experimental coverage, and this is unfortunate because most of arc magmas belong to this category. Moretti et al. (2003) devised a general solubility model that should be applicable to a wide range of silicate melt compositions, including those hydrous. However, although based on a rigorous, as well as promising, thermodynamic description of melt-fluid equilibria, the current version of the model is quite complex to implement and is presently restricted to conditions of melt undersaturation with respect to a Fe-S-O sulphide melt.

In the present paper, we follow a more pragmatical approach and derive an empirical solubility model by considering the existing experimental database on geologically relevant silicate liquids. We have deliberately ignored the wealth of data existing in the metallurgical literature, since 1) it is exclusively based on dry compositions, 2) it concerns silicate melt compositions far outside the compositional spectrum displayed by terrestrial magmas, and 3) it covers temperatures greater than those typical of Earth's magmatism. Our first target is to build a model that allows us to compute the $f \mathrm{~S}_{2}$ of basaltic to intermediate hydrous melts, using as input parameters $P, T, f \mathrm{O}_{2}$ and melt composition. Although we believe that the model described below retrieves the correct order of magnitude in terms of $f \mathrm{~S}_{2}$, we envision it as an intermediate step that should help define future experimental strategies to obtain high pressure solubility data onto which more rigorous thermodynamic approaches, such as that of Moretti et al. (2003), will be calibrated. The second target of this report is the application of this model to Italian volcanoes for which there exists a combined data set of pre-eruption $\mathrm{H}_{2} \mathrm{O}$, $\mathrm{CO}_{2}$ and $\mathrm{S}$ concentrations, in addition to other intensive parameters ( $T$ and $f \mathrm{O}_{2}$ ). We considered Stromboli, Vesuvius, Vulcano and Etna volcanoes, for which there are melt inclusion constraints on pre- to syn-eruptive volatile abundances. We calculated the equilibrium fluid composition corresponding to the depth at which the melt inclusion were saturated in fluid. The rationale here is clear: to constrain fluid compositions from depth to near surface conditions and compare it with the observed gas composition measured at the exit (see Scaillet and Pichavant, 2003). The combination of the two sets of data (calculation and observation) should allow a better use of volcanic gases as monitoring tools during on-going volcanic crisis.

\section{An empirical model for hydrous basaltic melts}

We attempted to devise a general empirical model in which the different effects of $f \mathrm{O}_{2}, f \mathrm{~S}_{2}$ and $T$ on the melt sulphur content, as well as the melt composition, are explicitly taken into account. Several equations were tested and the following was found to give satisfactory results

$$
\begin{aligned}
& \log \mathrm{S}=a P+b T+c \Delta \mathrm{NNO}^{3}+d \Delta \mathrm{NNO}^{2}+ \\
& +e \Delta \mathrm{NNO} \Delta \mathrm{FFS}+f \Delta \mathrm{FFS}+\sum g_{i} W_{i}
\end{aligned}
$$

where $\mathrm{S}$ is the total sulphur concentration in ppm, $P$ the pressure in bar, $T$ the temperature in ${ }^{\circ} \mathrm{C}, \Delta \mathrm{NNO}$ and $\triangle \mathrm{FFS}$ are the referenced $\mathrm{fO}_{2}$ and $f \mathrm{~S}_{2}$ as explained below, $W_{i}$ represents the weight $\%$ of oxide $i$, and $a, b, c, d, e, f$ and $g_{i}$ are fitted parameters listed in table I. The summa- 
Table I. Regression coefficients for the empirical model of sulphur solubility.

\begin{tabular}{lr}
\hline \hline$P$ & $7.28 \mathrm{E}-06$ \\
$\mathrm{NNO}^{3}$ & 0.00488128 \\
$\mathrm{NNO}^{2}$ & 0.0818873 \\
$\mathrm{NNOFFS}$ & -0.0224068 \\
$T$ & 0.00084107 \\
$\mathrm{FFS}$ & 0.22801636 \\
$\mathrm{SiO}_{2}$ & -0.012467 \\
$\mathrm{Al}_{2} \mathrm{O}_{3}$ & -0.0015766 \\
$\mathrm{Fe}_{2} \mathrm{O}_{3}$ & 0.37362348 \\
$\mathrm{FeO}_{\mathrm{MgO}}$ & 0.0674383 \\
$\mathrm{MgO}$ & 0.01121929 \\
$\mathrm{CaO}$ & 0.02000831 \\
$\mathrm{Na}_{2} \mathrm{O}$ & 0.05644745 \\
$\mathrm{~K}_{2} \mathrm{O}$ & -0.0248037 \\
$\mathrm{TiO}_{2}$ & 0.00672403 \\
$\mathrm{H}_{2} \mathrm{O}$ & 0.06868295 \\
$\mathrm{OH}$ & 0.05778453 \\
\hline
\end{tabular}

tion is carried over all major oxides, including $\mathrm{FeO}, \mathrm{Fe}_{2} \mathrm{O}_{3}, \mathrm{OH}^{-}$and $\mathrm{H}_{2} \mathrm{O}$. The $\mathrm{Fe}^{2+} / \mathrm{Fe}^{3+}$ ratios of experimental glasses were calculated using the empirical model of Kilinc et al. (1984), whereas the water contribution was split into hydroxyl and molecular water using the method of Zhang (1999). The third order polynomial function is necessary to reproduce the dissymetrical inverted bell-shaped pattern (e.g., Katsura and Nagashima, 1974), while the crossed $f \mathrm{O}_{2}-f \mathrm{~S}_{2}$ term is needed to take into account the effect of varying $f \mathrm{~S}_{2}$ on the relationship between $\mathrm{fO}_{2}$ and $\mathrm{S}$ in melt (see Clemente et al. 2004). Using mole fractions instead of weight $\%$ oxides, or any other intensive parameters (i.e. $f \mathrm{H}_{2}$ in lieu of $f \mathrm{O}_{2}$ ), does not improve the quality of the fit. Similarly, to account for the compositional dependence various norm projections were tested including the CIPW norm, but none was found to decrease the residuals. As for $f \mathrm{O}_{2}$, which is referenced to the NNO solid buffer, we have referenced $f S_{2}$ to the irontroilite solid buffer (Fe-FeS or FFS) such that

$$
\Delta \mathrm{FFS}=\log \mathrm{fS}_{2}(\text { melt })+\log \mathrm{fS}_{2}(\mathrm{FFS})
$$

in which the $f \mathrm{~S}_{2}$ of the Fe-FeS buffer is given by (Froese and Gunter, 1976)

$$
\begin{aligned}
& \log f \mathrm{~S}_{2}(\mathrm{FFS})=\{(2 / 1.987 T)[-0.2655(P-1)+ \\
& -35910+12.56 T]\} / 2.302581
\end{aligned}
$$

where $P$ is in bar and $T(K)$ is the absolute temperature.

We derived a set of fitted $a \ldots g_{i}$ parameters for eq. (2.1) by linear regression considering the data bases of Luhr (1990), O'Neill and Mavrogenes (2002), Katsura and Nagashima (1974) on rhyodacite melts, in addition to those of Clemente et al. (2004). As stated above, although the existing experimental database is considerably larger, we restricted the regression procedure to the above studies for the following reasons: first, all works were specifically aimed at exploring the behaviour of sulphur in geological melts and are thus of direct relevance to magmatic contexts; second, they were carried out within $P-T-f \mathrm{O}_{2}-f \mathrm{~S}_{2}-f \mathrm{H}_{2} \mathrm{O}$ conditions that closely approach those under which natural magmas evolve; third, use of the complete database is not warranted since much of it concerns slags or synthetic silicate melts of metallurgical, rather than geological, interest. Because our model is empirical, including this database will have the undesirable but unavoidable consequence that one atmosphere data overwhelmingly dominate over those obtained at high pressure and thus that the fitted parameters be biased toward anhydrous compositions. Preliminary fitting procedures used the database of Haughton et al. (1974). However, the extensive work of O'Neill and Mavrogenes (2002) on dry mafic melts at one bar has shown that a substantial part of the experimental database gathered by Haughton et al. (1974) does not obey expected thermodynamic relationships, and for this reason we have not included this work in our database.

The selected database consists therefore of 64 hydrous rhyolitic compositions (Clemente et al. (2004) plus three charges of Scaillet et al. (1998) for which $f S_{2}$ has been measured using the same technique than in Clemente et al. (2004)), 72 hydrous rhyolite-andesite compositions (Luhr, 1990), 333 dry mafic to ultramafic 
compositions (O’Neill and Mavrogenes, 2002), and 5 dry rhyodacite compositions of Katsura and Nagashima (1974). There is therefore a $30 / 70$ repartition between hydrous and dry compositions. The experiments of Luhr (1990) and Clemente et al. (2004) are the only ones in which both $f \mathrm{O}_{2}$ and $f \mathrm{~S}_{2}$ are known for hydrous compositions, and cover an $\mathrm{fO}_{2}$ range between NNO-1 up to NNO+3, a total pressure of 100$400 \mathrm{MPa}$, a temperature $800-1000^{\circ} \mathrm{C}$, for melt

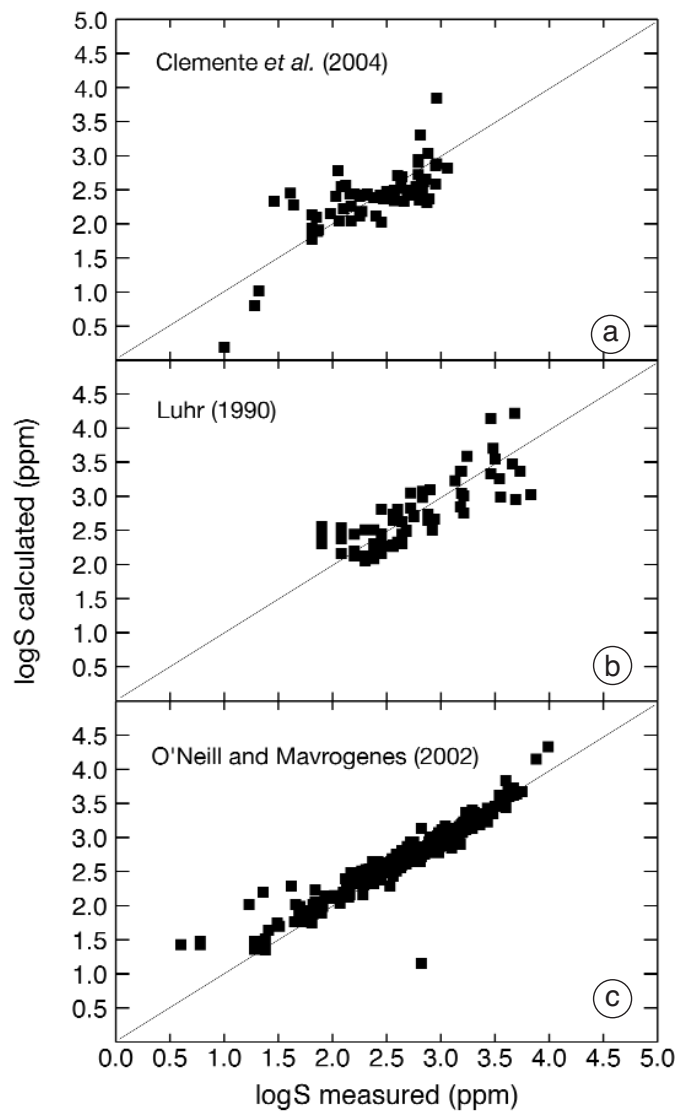

Fig. 1a-c. Comparison between measured and calculated melt sulphur concentrations for the three main experimental data sub set used to calibrate the empirical model (eq. (2.1), see text). a) rhyolitic compositions (Clemente et al., 2004; Scaillet et al., 1998; Katsura and Nagashima, 1978); b) intermediate compositions (Lurh, 1990); c) basaltic composition (O’Neill and Mavrogenes, 2002). water contents up to $8 \mathrm{wt} \%$, the melt compositions spanning a $\mathrm{SiO}_{2}$ range of 57-80 wt $\%$ on an anhydrous basis. The experiments of Katsura and Nagashima (1974) were included in the regression in an effort to constrain the sulphur solubility in silicic compositions under dry, i.e. low pressure, conditions. The database of O'Neill and Mavrogenes was chosen among others (e.g., Buchanan and Nolan, 1979; apart from that of Haughton et al., 1974, for the reason given above) because of its systematic variation of melt composition at constant $f \mathrm{O}_{2}$ and $f \mathrm{~S}_{2}$, which allows a better evaluation of the compositional dependence of sulphur solubility (i.e. the $g_{i}$ terms in eq. (2.1)). The fitted parameters are listed in table I.

Figure 1a-c shows that the model reproduces observed sulphur concentrations of the whole data set over more than 3 orders of magnitude (10-11900 ppm), with no apparent systematic divergence from the $1 / 1$ correlation line within any of the three main data subsets, except in the low concentration range. Considering that the database covers a wide compositional range $\left(\mathrm{SiO}_{2}\right.$ ranging from 35 to $\left.80 \mathrm{wt} \%\right)$, as well as widely differing $P$ - $T$-fluid fugacities conditions, the agreement between observed and calculated sulphur concentrations is considered satisfactory. In terms of $f \mathrm{~S}_{2}$, the model reproduces measured $f \mathrm{~S}_{2}$ within an average of $0.65 \log$ unit, over more than $15 \log$ units when normalised to the FFS solid buffer. Inspection of fig. 1a-c shows nevertheless that hydrous melts are not as well reproduced by the model, which is a reflection of the difficulty in accurately controlling $f \mathrm{~S}_{2}$ in high pressure experiments, since there is no buffering technique which allows to measure $f \mathrm{~S}_{2}$ with a precision similar to that of $f \mathrm{O}_{2}$ or $f \mathrm{H}_{2}$. Given that there exist solubility models for rhyolite compositions (Clemente et al., 2003) and for dry mafic melts (e.g., Wallace and Carmichael, 1992; O'Neill and Mavrogenes, 2002), this empirical model is intended primarily to be used for melt compositions currently lacking experimental constraints, that is, hydrous mafic melts.

Equation (2.1) is merely a convenient mathematical way to describe the interdependence between the various parameters that control the sulphur solubility in silicate melts. As such the 
fitted parameters have clearly no thermodynamical meaning. Yet, it is useful to consider at this stage the individual effect of some of the parameters on the calculated $f \mathrm{~S}_{2}$ (or sulphur solubility) to appreciate their relative importance on sulphur behaviour in hydrous magmas. All parameters with a positive value increase the sulphur solubility, when everything else is kept constant. For instance at constant $f \mathrm{O}_{2}, f \mathrm{~S}_{2}$, $P$ and melt composition, a temperature increase produces an increase in melt sulphur content. The same is true for $P$ which suggests that, in hydrous systems, an increase in pressure increases the sulphur solubility, a trend opposite to that found for dry mafic melts saturated in an immiscible sulphide liquid (see Mavrogenes and O'Neill, 1999). Of the melt components, only $\mathrm{SiO}_{2}, \mathrm{Al}_{2} \mathrm{O}_{3}$ and $\mathrm{K}_{2} \mathrm{O}$ have negative signs. Although this is as expected for $\mathrm{SiO}_{2}$ and $\mathrm{Al}_{2} \mathrm{O}_{3}$ because both components increase the degree of melt polymerisation, and thus they decrease its capacity to exchange sulphur ions with free oxygens, the negative sign found for $\mathrm{K}_{2} \mathrm{O}$ is more surprising since this element is often positively correlated with melt sulphur content (see Métrich and Clocchiatti, 1996). Whether this effect is real or is merely a reflection of a compositional bias in the database cannot be solved in the present study. The large value found for $\mathrm{Fe}_{2} \mathrm{O}_{3}$ may indicate preferential association of oxidized sulfur groups with $\mathrm{Fe}^{3+}$ melt components but we stress that in the database, oxidized melts are mostly intermediate to silicic compositions with a low bulk $\mathrm{FeO}$ and thus a relatively low $\mathrm{Fe}_{2} \mathrm{O}_{3}$ content. Experiments performed on iron-rich basalts have been mostly performed at low $\mathrm{fO}_{2}$, and the behaviour of sulphur in dry oxidized basalt still demands experimental investigations. A last aspect of interest concerns the role of water. Both molecular $\mathrm{H}_{2} \mathrm{O}$ and hydroxyl group have strong positive values which suggests that addition of water to a silicate melt held at constant $P-T-f \mathrm{O}_{2}-f \mathrm{~S}_{2}$ conditions significantly increases its melt sulphur content. We note, however, that because high pressure experiments are also those that are hydrous in the database, correctly discriminating the effects of pressure and water content on sulphur solubility is not yet possible. Overall the empirical model can be considered as calibrat- ed in the pressure range 1-4000 bar, temperature range $800-1400^{\circ} \mathrm{C}$, melt water content range $0-10 \mathrm{wt} \%, f \mathrm{O}_{2}$ range $\mathrm{NNO}-2$ to $\mathrm{NNO}+3$, and melt sulphur contents 50-10000 ppm. Melt compositions not yet considered and to which the model should be applied with caution are evolved alkali-rich magmas, such as phonolites and peralkaline rhyolites.

\section{Calculation of fluid phase composition}

To calculate the fluid phase composition we follow the same approach as Scaillet and Pichavant (2003) who determined the fluid compositions of a number of intermediate to silicic arc magmas. They also attempted to constrain the fluid phase of some hydrous arc basalts, using a simplified version of the Wallace and Carmichael (1992) model. The calculations were performed considering that the fluid composition can be described in the C-O-H-S system. We thus ignore the contribution of halogens, in particular $\mathrm{F}$ and $\mathrm{Cl}$, although we recognise that those species may play an important role in the evolution of magmatic fluids (see Carroll and Webster, 1994), especially in alkali-rich magmas (e.g., Métrich, 1990; Webster and De Vivo, 2002).

The species considered are $\mathrm{H}_{2} \mathrm{O}, \mathrm{H}_{2}, \mathrm{CO}_{2}$, $\mathrm{CO}, \mathrm{CH}_{4}, \mathrm{H}_{2} \mathrm{~S}, \mathrm{SO}_{2}, \mathrm{~S}_{2}$ and $\mathrm{O}_{2}$. To calculate the fluid compositions we use as input parameters, $f \mathrm{O}_{2}, f \mathrm{~S}_{2}$ and $f \mathrm{H}_{2} \mathrm{O}$. The thermodynamic model of water solubility for basalt of Dixon et al. (1995) is used to calculate $f \mathrm{H}_{2} \mathrm{O}$ from the measured melt $\mathrm{H}_{2} \mathrm{O}$ content. The $\mathrm{fO}_{2}$ is constrained from petrological studies (i.e., spinel-olivinemelt equilibria; Ballhaus et al., 1991) or sulphur speciation (e.g., Métrich and Clocchiatti, 1996). The $f S_{2}$ is calculated from eq. (2.1).

At any fixed $P$ and $T$, fixing $f \mathrm{O}_{2}, f \mathrm{~S}_{2}$ and $f \mathrm{H}_{2} \mathrm{O}$ allows us to calculate the fugacities of all remaining species. For pressures below 5 kbar, we use the Modified Redlich Kwong equation of state (see Holloway, 1977; Flowers, 1979) with mixing rules as given by Ferry and Baumgartner (1987). At higher pressure, we use the corresponding state equation of Shi and Saxena (1992) and Saxena and Fei (1987) to calculate the fugacities of pure species. The fugacities of the species in the fluid mixture were derived us- 
ing the Lewis and Randall rule: the fugacity coefficient of species $i$ in the mixture equals that of pure species $i$ at the same $P$ and $T$.

Because the fluid pressure is unknown, the calculation must be done iteratively. The following procedure was adopted. We first fix $P$, $T$, and calculate the corresponding $f \mathrm{H}_{2} \mathrm{O}$ and $f \mathrm{~S}_{2}$ from melt inclusion data. This results in a $\mathrm{fCO}_{2}$ which is used to calculate the equilibrium $\mathrm{CO}_{2}$ content of the melt, using the solubility model of Dixon et al. (1995). This $\mathrm{CO}_{2}$ content is then compared to that measured in the melt inclusion and if the difference between observed and calculated values exceeds $10 \mathrm{ppm}$, the calculation is performed again at a different pressure until the test is fullfilled. Because $P$ variations affect both $f \mathrm{~S}_{2}$ and $f \mathrm{H}_{2} \mathrm{O}$ for a given set of $T$ $\mathrm{fO}_{2}$-melt composition values, tests are also performed on the difference between observed and calculated values in melt $\mathrm{S}$ and $\mathrm{H}_{2} \mathrm{O}$ contents. The pressures of fluid saturation listed below reproduce observed $\mathrm{H}_{2} \mathrm{O}, \mathrm{CO}_{2}$ and $\mathrm{S}$ melt contents to $\pm 0.01 \mathrm{wt} \%, 10 \mathrm{ppm}, 1 \mathrm{ppm}$, respectively.

For alkali-rich basalts, we corrected for the alkali effect using the following method which is based on the approach of Dixon (1997) to evaluate the increase in $\mathrm{CO}_{2}$ solubility resulting from an increase in melt alkalinity. For a given calculated $f \mathrm{CO}_{2}$, we first determine the melt $\mathrm{CO}_{2}$ content using the solubility model of Dixon et al. (1995) which is calibrated on MORB composition. This amount of $\mathrm{CO}_{2}$ is then adjusted using the following empirical fit:

$$
\begin{aligned}
& \mathrm{CO}_{2}(\mathrm{ppm})=\mathrm{CO}_{2 \text {-моRв }}(\Pi-0.472) 0.8092 * \\
& * \Pi+\mathrm{CO}_{2 \text {-моRв }}
\end{aligned}
$$

where $\mathrm{CO}_{2-\mathrm{MORB}}$ is the $\mathrm{CO}_{2}$ content of a MORB melt at $P$ and $T$ (in ppm) calculated using the model of Dixon et al. (1995), and $\Pi$ is a compositional parameter devised by Dixon (1997) to evaluate the effect of metal cations on $\mathrm{CO}_{2}$ solubility, and is equal to

$$
\begin{aligned}
& \Pi=-6.5\left(\mathrm{Si}^{4+}+\mathrm{Al}^{3+}\right)+20.17\left(\mathrm{Ca}^{2+}+0.8 \mathrm{~K}^{+}+\right. \\
& \left.+0.4 \mathrm{Mg}^{2+}+0.4 \mathrm{Fe}^{2+}\right)
\end{aligned}
$$

where the $\mathrm{Si}, \mathrm{Al} \ldots$ are cationic fractions, and
$\mathrm{Fe}^{2+}$ is computed from total iron expressed as $\mathrm{FeO}_{\text {tot }}$ (only $\mathrm{Fe}^{2+}$ in Dixon, 1997). Equation (3.1) was derived by linear regression of solubility data (see Holloway and Blank, 1994; Dixon, 1997) obtained at $1 \mathrm{kbar}$ and $1200^{\circ} \mathrm{C}$ on MORB tholeiite, Kilauea tholeiite, basanite and leucitite melts which encompass a $\Pi$ range of 0.47 (MORB) to 2.35 (leucitite). Equation (3.1) back calculates experimental solubility data with an average standard deviation of $80 \mathrm{ppm}$ at $1 \mathrm{kbar}$. Inspection of experimental data shows that in fact the $\mathrm{CO}_{2}$ solubility of mafic melts is constant within analytical uncertainties for $\Pi$ in the range 0.47 0.79 , so that we have applied eq. (3.1) only to melt compositions having a $\Pi$ value higher than 0.8 . Although the correction factor is likely to vary with pressure and temperature, we have applied eq. (3.1) at all $P$ and $T$ since there are not enough data to properly evaluate this effect over a large range of $P-T$ conditions.

We note, in addition, that the compositions used to derive eq. (3.1) are significantly less alkali-rich than some of the basalts erupted at Italian volcanoes: in particular, the tephrites of Vesuvius have $\mathrm{K}_{2} \mathrm{O}$ contents almost twice higher than that of the most alkali-rich composition used to derive eq. (3.1). The strong correlation observed in experimental mafic melts between

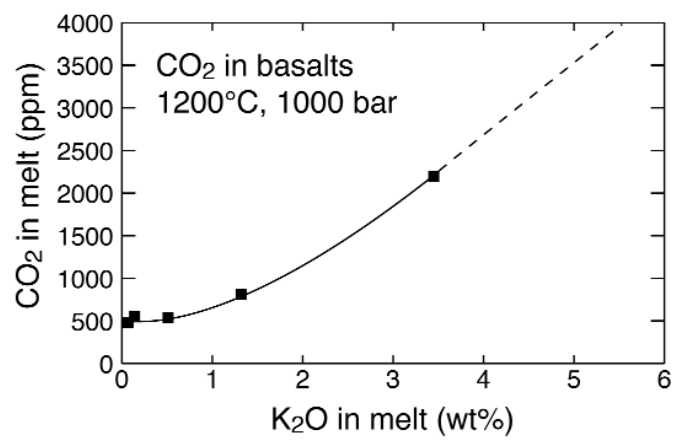

Fig. 2. Correlation between dissolved $\mathrm{CO}_{2}$ and the $\mathrm{K}_{2} \mathrm{O}$ content of experimental basaltic melts used to determine the solubility of $\mathrm{CO}_{2}$ at 1000 bar and $1200^{\circ} \mathrm{C}$. See Dixon (1997) for the source of data. Vesuvius tephrites, between 4 and $5 \mathrm{wt} \% \mathrm{~K}_{2} \mathrm{O}$, could have $\mathrm{CO}_{2}$ solubilities close, or in excess, to 4000 ppm, or nearly 10 times more than MOR basalts ( $c a$. $500 \mathrm{ppm}$ under these conditions). 
$\mathrm{K}_{2} \mathrm{O}$ and $\mathrm{CO}_{2}$ content (fig. 2) suggests that $\mathrm{K}_{2} \mathrm{O}$ may have a decisive role on $\mathrm{CO}_{2}$ solubility in mafic melts perhaps far outweighing that of other metal cations. Simple extrapolation of the trend shown on fig. 2 would imply that $\mathrm{CO}_{2}$ solubility in a tephrite with $5 \mathrm{wt} \% \mathrm{~K}_{2} \mathrm{O}$ at $1 \mathrm{~kb}$ and $1200^{\circ} \mathrm{C}$ could be nearly ten times that of MORB or 3000-4000 ppm, while application of the method of Dixon (1997) with $\Pi=1$ predicts a much smaller increase in $\mathrm{CO}_{2}$ solubility (from ca. $500 \mathrm{ppm}$ for a MORB to $724 \mathrm{ppm}$ for a tephrite). In support of this enhanced $\mathrm{CO}_{2}$ solubility are the phase equilibria of Trigila and De Benedetti (1993), which have shown that addition of $\mathrm{CO}_{2}$ to dry tephrite at $2 \mathrm{kbar}$ depresses the liquidus temperatures of pyroxene, leucite and plagioclase by $50-75^{\circ} \mathrm{C}$ with estimated $\mathrm{CO}_{2}$ concentrations in melt in excess of $1 \mathrm{wt} \%$ (see also Freda et al.,1997, for similar findings on phonotephritic magmas of the Alban Hills). A freezing point depression effect in a given silicate- $\mathrm{CO}_{2}$ system implies a significant solubility of $\mathrm{CO}_{2}$ in the melt. Although such a potassium effect on $\mathrm{CO}_{2}$ solubility cannot be rigorously modeled at present, the above observations suggest that the pressures of fluid saturation calculated here could be largely overestimated for mafic melt compositions that contain significantly more $\mathrm{K}_{2} \mathrm{O}$ than the rock melts so far investigated in experimental studies on $\mathrm{CO}_{2}$ solubility.

In summary we believe that mafic melts moderately enriched in $\mathrm{K}_{2} \mathrm{O}$ relative to MORB can have their $\mathrm{CO}_{2}$ solubility, and thus their pressure of fluid saturation, correctly estimated (to within $0.5 \mathrm{kbar}$ ) by the method explained above. This is the case for most of the mafic magmas erupted at Etna, Stromboli and Vulcano. In contrast, there exists the possibility that the pressures of fluid saturation calculated in this work for $\mathrm{K}_{2} \mathrm{O}$-rich mafic magmas such as Vesuvius tephrites, are largely overestimated, perhaps by as much as several kilobars. This indicates that there is an urgent need of experimental constraints on $\mathrm{CO}_{2}$ solubility in alkali-rich basalts.

\section{Source of data}

In this section we briefly review the present status of knowledge on pre-eruptive $\mathrm{H}_{2} \mathrm{O}-\mathrm{CO}_{2}$ -
S melt concentrations as well as of $P-T-f \mathrm{O}_{2}$ of the different volcanoes considered. We are primarily interested in works where those three volatiles have been determined (e.g., Marianelli et al., 1999; Métrich et al., 2001). However, we also considered melt inclusion data sets lacking $\mathrm{CO}_{2}$ determination but for which both $\mathrm{H}_{2} \mathrm{O}$ and $\mathrm{S}$ are known (e.g., Marianelli et al., 1995; Métrich et al., 1993; Cioni et al., 1995). Although the lack of $\mathrm{CO}_{2}$ constraints prevents the calculation of the pressure of fluid saturation and fluid composition, $\mathrm{H}_{2} \mathrm{O}$ and $\mathrm{S}$ abundances can still be used to infer $f \mathrm{~S}_{2}$, provided there are $T-f \mathrm{O}_{2}$ constraints. In such a case, the pressure for calculation in eq. (2.1) is that corresponding to the $\mathrm{H}_{2} \mathrm{O}$ solubility. While this pressure is clearly a minimum, in terms of $f \mathrm{~S}_{2}$ calculation the error introduced by this uncertainty is minor, compared to that due to $\mathrm{fO}_{2}$ : a pressure increase of $4 \mathrm{kbar}$ decreases the calculated $\log f \mathrm{~S}_{2}$ by $0.5 \mathrm{log}$ unit. In the following, we focus primarily on mafic primitive melts, since it is the injection of mafic fresh magmas that is more likely to re-awaken or trigger a new explosive event, as illustrated by the April 5th, 2003 event at Stromboli.

\subsection{Stromboli}

We restricted our calculations to melt inclusions analysed by Métrich et al. (2001), who studied the products of paroxysmic eruptions such as that of the August 23, 1998 explosion, during which crystal-rich scoria and highly vesicular yellow pumices were erupted. The first type of rock is interpreted to represent quenched fragments of a crystal-rich degassed magma that was resident in a very shallow magma chamber. This reservoir was intercepted by a rising batch of crystal-poor and volatilerich magma, now represented by the yellow pumice. Melt inclusion constraints on volatile abundances were obtained on both type of magmas, giving pressure for fluid saturation up to 4 kbar for the volatile-rich yellow pumice (Métrich et al., 2001; Bertagnini et al., 2003). Temperature constraints come from melt inclusion homogeneisation during heating stage experiments which indicate that the yellow 
pumice was at $1125-1140^{\circ} \mathrm{C}$, whereas the crystal-rich scoria was at a slightly lower temperatures of $1100-1125^{\circ} \mathrm{C}$. The pre-eruptive temperature for the yellow pumice has been confirmed by recent phase equilibrium work (Di Carlo et al., 2004). Here we use temperatures of 1140 and $1100^{\circ} \mathrm{C}$ for the pumice and scoria rocks, respectively. The redox state of Stromboli magmas was inferred through the determination of sulphur speciation (Métrich and Clocchiatti, 1996; Métrich et al., 2002) which yields an average $f \mathrm{O}_{2}$ of $\mathrm{NNO}+0.95$. For the calculation of fluid phase corresponding to the scoria or degassed magmas, we assumed that the pre-eruptive melt contained $40-50 \mathrm{ppm} \mathrm{CO}_{2}$, since this species could not be detected by FTIR in scoria melt inclusions.

\subsection{Vesuvius}

For Vesuvius there is a large body of data on melt inclusion chemistry (e.g., Vagelli et al., 1992, 1993; Cioni et al., 1995, 1998; Marianelli et al., 1995, 1999; Belkin et al., 1998; Lima et al., 1999; Signorelli and Capaccioni, 1999; Signorelli et al., 1999; Cioni, 2000; Raia et al., 2000; Webster et al., 2001), but for Stromboli only recently has the $\mathrm{CO}_{2}$ in melt inclusions been determined using micro beam techniques (Marianelli et al., 1999; Signorelli et al., 1999; Cioni, 2000). We did not consider works done on felsic phonolites, however, since eq. (2.1) is not yet calibrated for these compositions. To minimise errors arising from differences in sulphur and water determinations between different research groups, we used only the data sets of Cioni et al. (1995), and Marianelli et al. $(1995,1999)$ in which at least both $\mathrm{S}$ and $\mathrm{H}_{2} \mathrm{O}$ were determined using the same instrument and analytical procedure. Most of the analysed inclusions correspond to primitive melts for which heating stages experiments give homogenisation temperatures of $c a .1100-1150^{\circ} \mathrm{C}$ (e.g., Cioni et al., 1995; Marianelli et al., 1995). For melt inclusions lacking such information, temperatures were determined using the $\mathrm{CaO}$ in melt geothermometer of Cioni et al. (1998). The redox state is known indirectly from sulphur speciation determination either on bulk rocks, lava or pumices (Marini et al., 1998), or in melt inclusions (Métrich et al., 2002), both yielding an $f \mathrm{O}_{2}$ of $c a$. $\mathrm{NNO}+1.2$.

\subsection{Vulcano}

Melt inclusions of Vulcano magmas have been analysed by Clocchiatti et al. (1994a,b) and Gioncada et al. (1998). The latter work showed that the $\mathrm{CO}_{2}$ content of primitive melt inclusions is below the FTIR detection limit, which yields a maximum $\mathrm{CO}_{2}$ content of about $50 \mathrm{ppm}$. The storage conditions of the reservoir that fed the 1888-1890 eruption, during which rhyolite to trachytic magmas were ejected, were inferred by Clocchiatti et al. (1994a) to be: a pressure depth of $80 \mathrm{MPa}$, melt water contents in the range $1-1.5 \mathrm{wt} \%$, and temperatures between $1000-1100^{\circ} \mathrm{C}$. This shallow reservoir is inferred to be connected to a deeper one where intermediate and mafic magmas reside. These are assumed to be equivalent to primitive melt inclusions in La Sommata basalts, whose homogeneisation temperature is $1180 \pm 20^{\circ} \mathrm{C}$ (Gioncada et al., 1998). The depth of the felsic upper reservoir provides an upper bound for the mafic part, which is estimated to lie at $70-110 \mathrm{MPa}$ (Gioncada et al., 1998). Measured melt water contents of the least differentiated magmas ( $\mathrm{La}$ Sommata melt inclusions) are in the range 2.1$3.8 \mathrm{wt} \%$, that is they are higher than their potential felsic derivatives (Clocchiatti et al., 1994a; Gioncada et al., 1998), suggesting an open system behaviour with respect to volatiles (Clocchiatti et al., 1994b). A similar observation can be made for sulphur which reaches maximum values of $2872 \mathrm{ppm}$ in the most mafic melts analysed (Clocchiatti et al., 1994b). The redox state of mafic magmas has been inferred from sulphur speciation to be at $\mathrm{NNO}+$ +0.72 (Métrich and Clocchiatti, 1996; Métrich et al., 2002).

To calculate the fluid phase compositions we used the melt inclusions analyses reported by Clocchiatti et al. (1994a) assuming that they all contained ca. 40-50 ppm dissolved $\mathrm{CO}_{2}$. Thus, the calculated fluid compositions correspond to the maximum $\mathrm{CO}_{2}$ content that can be expected at Vulcano given the available melt 
inclusion constraints. In addition, we calculated the $f \mathrm{~S}_{2}$ corresponding to melt inclusions of Clocchiatti et al. (1994b), by assuming that mafic melts have a pre-eruptive water content of $1 \mathrm{wt} \%$, whereas that of more felsic compositions (shoshonite to latite-rhyolites) has been set at $1 \mathrm{wt} \%$.

\subsection{Etna}

Unlike the three previous volcanoes, there are currently no published combined sets of pre-eruptive $\mathrm{H}_{2} \mathrm{O}-\mathrm{CO}_{2}-\mathrm{S}$ contents of Etnean mafic melts. Existing melt inclusion studies have analysed either $\mathrm{S}$ and $\mathrm{Cl}$ (e.g., Clocchiatti and Métrich, 1984), $\mathrm{H}_{2} \mathrm{O}$ and $\mathrm{S}$ (Métrich et al., 1993), $\mathrm{CO}_{2}$ (Métrich and Mosbah, 1988), or $\mathrm{S}$ and $\mathrm{Cl}$ (Kamenetsky and Clocchiatti, 1996) but none has determined the concentration of those volatiles collectively in single melt inclusions. A literature survey shows that only the alkali basalt erupted in 1892 (Mt. Maletto), which is among the most primitive basalts yet erupted on Etna (Armienti et al., 1988), has had its preeruptive volatile content determined in full, albeit not necessarily on the same melt inclusions (Métrich and Mosbah, 1988 for $\mathrm{CO}_{2}$; and Métrich et al., 1993, for $\mathrm{H}_{2} \mathrm{O}$ and $\mathrm{S}$ ). There are thus surprisingly very few constraints on the volatile concentrations that could be used to determine fluid saturation pressures of Etnaean magmas, either past or present. Therefore, we adopted a different strategy relative to the three other volcanoes. We performed thermodynamic calculations at various pressures, assuming that a fluid phase is present, using available $\mathrm{H}_{2} \mathrm{O}$ and $\mathrm{S}$ melt concentrations coupled to petrological $T$ and $f \mathrm{O}_{2}$ constraints. The pressure range over which calculations were performed is derived from geophysical and petrological constraints, as summarised in the next sections.

The melt water contents of alkali basalts of Etna have been determined to be in the range 1$2.3 \mathrm{wt} \%$ (Trigila et al., 1990; Métrich et al., 1993), the higher value being regarded as the pristine pre-eruptive melt water content, based on phase equilibrium constraints (Métrich and Rutherford, 1998). Geochemical modelling has shown that these alkali basalts can be derived by $12-13$ wt $\%$ of olivine fractionation from a picritic basalt (Armienti et al., 1988), which therefore suggests that the water content of primary magmas at Etna is close to $0.8-2 \mathrm{wt} \%$, assuming closed system fractionation. As stated above, only melt inclusions of the 1892 eruption have had their $\mathrm{CO}_{2}$ content determined, with an average value of $588 \mathrm{ppm}$ (Métrich and Mosbah, 1988). This value is considered as a minimum because of the occurrence of carbonate crystals in the quenched melt inclusions (Métrich and Mosbah, 1988). Additional evidence for magmatic $\mathrm{CO}_{2}$ comes from its occurrence in the volcanic plume or in diffuse soil emanations (e.g., Allard et al., 1991; Bruno et al., 2001), and from the study of fluid inclusions associated to melt inclusions in lava phenocrysts or ultramafic nodules (Clocchiatti and Métrich, 1984; Sobolev et al., 1991; Frezzotti et al., 1991; Clocchiatti et al., 1992). Such fluid inclusions generally belong either to a low $\left(\mathrm{H}_{2} \mathrm{O}-\mathrm{CO}_{2}\right.$ or $\left.\mathrm{CO}_{2}\right)$ or a high $\left(\mathrm{CO}_{2}\right)$ density population. The high density inclusions yield maximum entrapment pressures of 6-7 kbar of a nearly pure $\mathrm{CO}_{2}$ fluid (Clocchiatti et al., 1992), whereas the low one yields pressures in the range 1-3 kbar (Clocchiatti and Métrich, 1984; Sobolev et al., 1991; Frezzotti et al., 1991). These observations suggest that any fluid phase coexisting with magma at depth must be $\mathrm{CO}_{2}$-rich .

For sulphur there is a considerable amount of analytical data (e.g., Métrich and Clocchiatti, 1989; Métrich et al., 1993), the highest concentration recorded in melt inclusions being $3800 \mathrm{ppm}$ (as quoted in Clocchiatti et al., 1992), though most have sulphur contents in the range 2500-3500 ppm (Clocchiatti and Métrich, 1984; Métrich and Clocchiatti, 1989, 1996). Generally the sulphur-rich melt inclusions are enclosed in the most magnesian olivines and they do not coexist with immiscible sulphide liquids (Métrich and Clocchiatti, 1989), while sulphur-poor inclusions hosted by Fe-rich olivine are occasionally saturated in a $\mathrm{Cu}$-rich sulphide melt (Métrich and Clocchiatti, 1989).

Petrological, geochemical, and geophysical evidence (e.g., Armienti et al., 1988; Bonaccorso, 1996, 2001; Tanguy et al., 1997; Murru et al., 1999) all points to the probable existence of a 
large deep reservoir beneath the volcano at a pressure depth range of 7-10 kbar, in which most of the primitive Etnaean magmas stagnate and fractionate to hawaiites (or trachybasalts). Such hawaiites constitute the bulk of the magmas outpoured over the last 300000 years. Similarly, geophysical, geodetic, geochemical, melt/ fluid inclusions, and phase equilibrium constraints, suggest that there are at least two additional shallow reservoirs feeding historical as well as on-going eruptions that lie at a pressure depth of about 1 and 3-4 kbar (e.g., Sobolev et al., 1991; Bonnacorso, 1996; Métrich and Rutherford, 1998; Murru et al., 1999; Caracausi et al., 2003). Temperatures of magma extrusion for the recent period have been estimated from a variety of approaches including direct measurement of lava flow (Tanguy et al., 1997), melt inclusion homogeneisation (e.g., Sobolev et al., 1991; Clocchiatti et al., 1992) and thermodynamical and phase equilibrium constraints (Trigila et al., 1990; Métrich and Rutherford, 1998) and all fall within a $T$ range of $1070-1100^{\circ} \mathrm{C}$. Temperatures of primitive alkali magmas stored at 7-10 kbar are estimated to be around $1200^{\circ} \mathrm{C}$ (Kamenetsky and Clocchiatti, 1996).

Redox conditions of Etnean basalts have been determined either through spinel-olivineorthopyroxene equilibria (e.g., Kamenetsky and Clocchiatti, 1996) or via the determination of sulphur speciation in glass inclusions (Métrich and Clocchiatti, 1996). The latter approach gives an $f \mathrm{O}_{2}$ corresponding to $\mathrm{NNO}+0.35$. The $f \mathrm{O}_{2}$ retrieved from spinel bearing assemblages in primitive melt inclusions from Mt. Maletto alkali basalt encompasses a range NNO up to $\mathrm{NNO}+1$, but we note that the $f \mathrm{O}_{2}$ calculated for another similar alkali basalt (Mt. Spagnolo) falls between $\mathrm{NNO}+1$ to $\mathrm{NNO}+2$, suggesting possibly more oxidizing conditions than those adopted here. Sato and Moore (1973) made intrinsic $f \mathrm{O}_{2}$ (and $f \mathrm{~S}_{2}$ ) measurements in gas streams from two hornito vents during the 1970 eruption and they found an $\mathrm{fO}_{2}$ of NNO-0.45, which Gerlach (1980) showed to be compatible with the restored gas compositions measured by Huntingdon (1973) during the same event.

In summary, because of the lack of confident pre-eruptive $\mathrm{CO}_{2}$ determinations, thermodynamic calculations of fluid composition co- existing with Etnaean mafic magmas were performed in the pressure range 400-10000 bar, in keeping with the petrological and geophysical constraints summarised above. Temperatures were either $1150^{\circ} \mathrm{C}\left(1 \mathrm{wt} \% \mathrm{H}_{2} \mathrm{O}\right)$ or $1130^{\circ} \mathrm{C}(2.23$ wt $\% \mathrm{H}_{2} \mathrm{O}$ ), based on melt inclusion heating stage experiments (Métrich and Clocchiatti, 1996). We considered melts water contents of 1 and 2.23 wt\% (Métrich et al., 1993) and melt sulphur contents of 1000-3400 ppm, with melt compositions as reported by Métrich et al. (1993). We explored $f \mathrm{O}_{2}$ conditions from NNO-0.45 to NNO+0.35, to ascertain the effect of $f \mathrm{O}_{2}$ on both $f \mathrm{~S}_{2}$ and fluid composition.

\section{Trends in $f S_{2}$ and sulphide saturation}

In all subsequent diagrams we use the ratio $\mathrm{CaO} / \mathrm{Al}_{2} \mathrm{O}_{3}$ as a differentiation index to illustrate variations in $f \mathrm{~S}_{2}$. The sulphide saturation is computed from the following equilibrium:

$$
\mathrm{FeO}_{\mathrm{m}}+1 / 2 \mathrm{~S}_{2}=\mathrm{FeS}_{\mathrm{m}}+1 / 2 \mathrm{O}_{2}
$$

using thermodynamic data for liquid $\mathrm{FeO}$ and $\mathrm{FeS}$ as given in O'Neill and Mavrogenes (2002). For all melt compositions we assume that $90 \%$ of iron is $\mathrm{FeO}$, and we use an activity coefficient for FeO of 1.4 (O'Neill and Mavrogenes, 2002). Given the relatively high redox state of the magmas, there may be less $\mathrm{Fe}^{2+}$ than the assumed value and thus the activity of $\mathrm{FeS}$ calculated $\left(a_{\mathrm{FeS}}\right)$ here should be considered as maximum values. The calculated $a_{\mathrm{FeS}}$ corresponds to pure FeS, however. Saturation in a sulphide liquid could arise if other components are present in solution, such as $\mathrm{Cu}$ or $\mathrm{Ni}$.

\subsection{Stromboli}

In fig. 3, two trends in $f \mathrm{~S}_{2}$ can be distinguished; MI of pumices define a flat trend with $f \mathrm{~S}_{2}$ values in the range 0.01 to 1 bar, the most primitive melt having the highest $f \mathrm{~S}_{2}$. The pumice trend joins that defined by the scoria MI, which is much more steep and spreads over nine orders of magnitude $f \mathrm{~S}_{2}$ at a nearly constant $\mathrm{CaO} / \mathrm{Al}_{2} \mathrm{O}_{3}$ ratio. This spread in $f \mathrm{~S}_{2}$ re- 


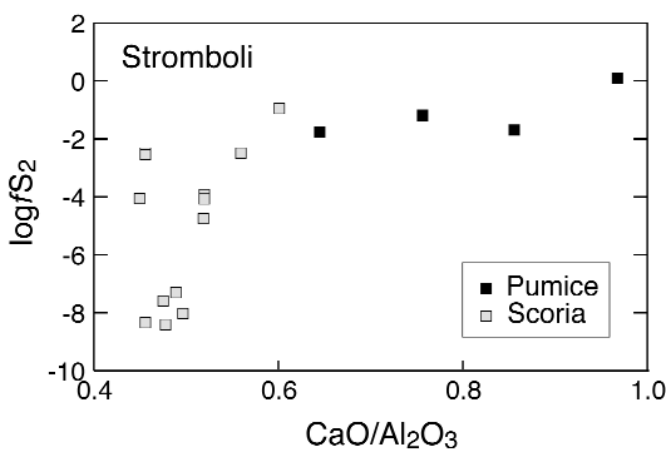

Fig. 3. Evolution of $f \mathrm{~S}_{2}$ with $\mathrm{CaO} / \mathrm{Al}_{2} \mathrm{O}_{3}$ ratio of Stromboli magmas. Because of massive clinopyroxene crystallisation in those magmas, fractionation is marked by a continuous decrease in the $\mathrm{CaO} / \mathrm{Al}_{2} \mathrm{O}_{3}$ ratio. The $f \mathrm{~S}_{2}$ is calculated from melt inclusion data (Métrich et al., 2001) and eq. (2.1) (see text). Pumice corresponds to magma emitted during paroxysmal events whereas scoria represents magmas erupted during Strombolian type eruptions.

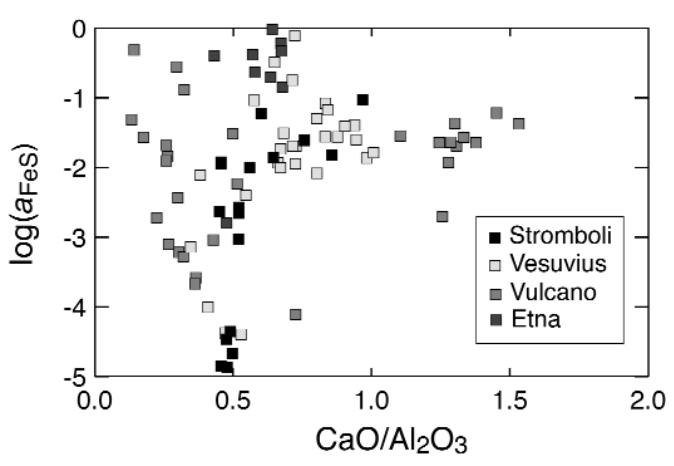

Fig. 4. Calculated activities of liquid FeS plotted versus the $\mathrm{CaO} / \mathrm{Al}_{2} \mathrm{O}_{3}$ ratio for the four volcanoes considered (see text for explanations). Note that almost all magmas are below saturation conditions with an immiscible sulphide liquid.

flects mostly the variable concentrations of sulphur analysed in various melt inclusions, since melt compositions in scoria, including water content, varies little (Métrich et al., 2001). The huge spread records the progressive degassing in sulphur of the magma that is stored in the shallow reservoir. The very steep slope indicates that degassing operates with little chemical modification of the environment. Inclusions in the scoria displaying the highest $f \mathrm{~S}_{2}$ may represent remnants of deep magma batches that intrude the upper reservoir or record incipient degassing of the deep magma batches during uprise. Melt inclusions in pumices were trapped at depths exceeding 3 kbar (see below). The $f S_{2}$ variations in this deeper reservoir appear to be much more restricted. The slight decrease observed corresponds to either selective loss of sulphur or, and more probably, to an increase in melt water content during fractionation, since water decrease $f \mathrm{~S}_{2}$ at a given melt sulphur content (see eq. (2.1)). The calculated $a_{\mathrm{FeS}}$ ranges from 0.1 down to 0.0001 (fig. 4), suggesting that mafic melts at Stromboli are far from reaching sulphide saturation. Removal of sulphur via sulphide disposal during fractionation is therefore probably not an efficient process at Stromboli.

\subsection{Vesuvius}

The data on Vesuvius are shown in fig. 5, being distinguished by the year of eruption. Two main trends emerge. The first corresponds to the 1906-1944 eruptions, whereas the second corresponds to the Pollena-Pompei-Avellino events. The 1906-1944 trend is somewhat analogous to the Stromboli in that less differentiated MI have higher and broadly constant $f \mathrm{~S}_{2}$ which, below a $\mathrm{CaO} / \mathrm{Al}_{2} \mathrm{O}_{3}$ ratio of 0.7 , sharply decrease down to a $\log f \mathrm{~S}_{2}$ of -7 . In contrast, MI analysed in Pollena-Pompei-Avellino define a broad trend of increasing $f \mathrm{~S}_{2}$ as fractionation proceeds, although for the Pompei MI a significant scatter is apparent, reaching values of $f \mathrm{~S}_{2}$ in excess of 100 bar. It is interesting to note that the first trend corresponds to events which characterise open conduit conditions, with semi-persistent Strombolian activity, as opposed to the other events which typify the establishment of a closed system following obstruction of the conduit during a long repose time preceding Plinian to sub-Plinian eruptions (e.g., Civetta et al., 1991; Civetta and Santacroce, 1992; Cioni et al., 1998). On this basis, the trend of decreasing $f \mathrm{~S}_{2}$ can be interpreted as reflecting 


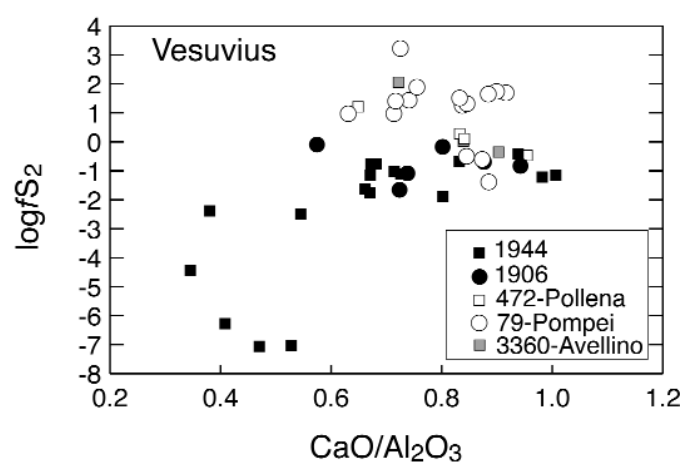

Fig. 5. Evolution of $f \mathrm{~S}_{2}$ with $\mathrm{CaO} / \mathrm{Al}_{2} \mathrm{O}_{3}$ ratio of Vesuvius magmas. The $f S_{2}$ is calculated from melt inclusion data (Cioni et al., 1995; Marianelli et al., 1995, 1999) and eq. (2.1) (see text). Different symbols correspond to the main eruptive events. The Pollena, Pompei and Avellino eruptions correspond to closed conduit conditions, while the 1944 and 1906 events are characteristic of open conduit conditions.

continuous loss of sulphur (and other volatiles) during magma uprise and emission to the surface (open conduit), in a way similar to that seen at Stromboli, whereas that of increasing $f \mathrm{~S}_{2}$ reflects a closed system in which sulphur has perhaps a dominant incompatible behaviour (its concentrations in the melt and fluid increase). As for Stromboli, all but one calculated $a_{\mathrm{FeS}}$ are significantly below unity (fig. 4) which again suggests that conditions for sulphide saturation are not reached in Vesuvius magmas, although they tend to approach it under closed conduit conditions. This may be one reason for the observed increase in $f \mathrm{~S}_{2}$ during differentiation.

\subsection{Vulcano}

The Vulcano data define two distinct groups (fig. 6); one corresponding to the most mafic MI (basaltic compositions) which cluster at $f \mathrm{~S}_{2}$ around $0.1 \mathrm{bar}$, and the second that corresponds to more evolved MI (shoshonitic to rhyolite compositions) that span values of $f \mathrm{~S}_{2}$ between several bars down to $10^{-8}$ bar, defining a trend negatively correlated with the $\mathrm{CaO} / \mathrm{Al}_{2} \mathrm{O}_{3}$ ratio (that is $f \mathrm{~S}_{2}$ increases with differentiation). This second trend is similar to that observed for the Pollena-Pompei-Avellino magmas discussed above. However, there is a significant gap between mafic and felsic magmas and it is unclear from the data whether this gap is real or if the $f \mathrm{~S}_{2}$ of the two groups overlap at a $\mathrm{CaO} / \mathrm{Al}_{2} \mathrm{O}_{3}$ ratio of around 1 . If this were true, then mafic melts must evolve towards lower $f \mathrm{~S}_{2}$ during fractionation. This hypothetical decrease could represent decompression of volatile-rich magmas during open conduit conditions, such as at Stromboli. Thereafter, once the partially degassed mafic batches have been emplaced at shallow level they further fractionate under closed system conditions during which $f \mathrm{~S}_{2}$ increases. Alternatively, the two groups may represent different levels of magma fractionation, one deep (both high and constant $\mathrm{CaO} / \mathrm{Al}_{2} \mathrm{O}_{3}$ ratio and $f \mathrm{~S}_{2}$ ) and one shallow (increasing $f \mathrm{~S}_{2}$ with fractionation). The $a_{\mathrm{Fes}}$ calculated are in general much lower than unity $\left(a_{\mathrm{FeS}}<0.01\right)$, but they do increase with fractionation such that the most felsic magmas may approach FeS saturation (fig. 4).

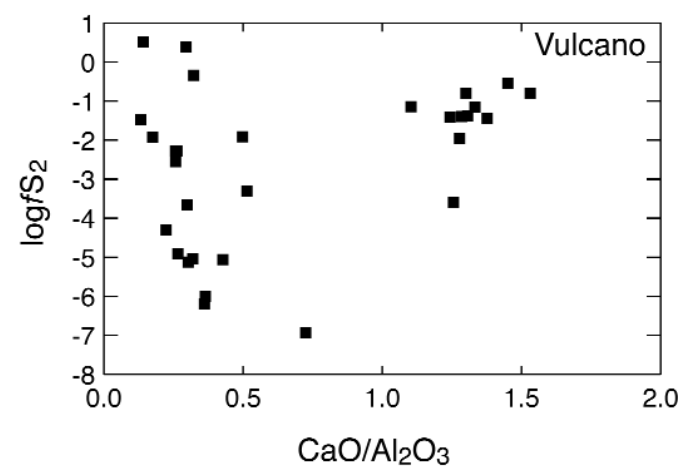

Fig. 6. Evolution of $f \mathrm{~S}_{2}$ with $\mathrm{CaO} / \mathrm{Al}_{2} \mathrm{O}_{3}$ ratio of Vulcano magmas. The $f \mathrm{~S}_{2}$ is calculated from melt inclusion data (Clocchiatti et al., 1994a,b; Gioncada et al., 1998) and eq. (2.1) (see text). Note that the most primitive melts (high $\mathrm{CaO} / \mathrm{Al}_{2} \mathrm{O}_{3}$ ratio) cluster at around $f \mathrm{~S}_{2}$ of $0.1 \mathrm{bar}$, whereas the rest of melts defines a negative trend of increasing $f \mathrm{~S}_{2}$ with differentiation. 


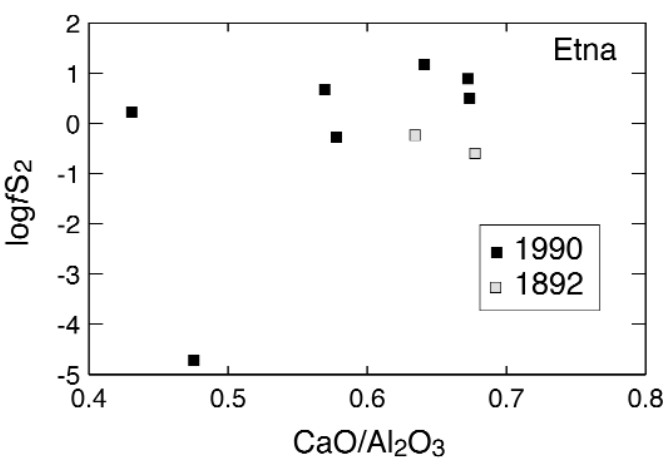

Fig. 7. Evolution of $f \mathrm{~S}_{2}$ with $\mathrm{CaO} / \mathrm{Al}_{2} \mathrm{O}_{3}$ ratio of Etna magmas. The $f \mathrm{~S}_{2}$ is calculated from melt inclusion data (Métrich et al., 1993) and eq. (2.1) (see text).

\subsection{Etna}

The Etna data (fig. 7) do not define any obvious trend, but this is largely due to the low number of MI analysed so far. The most primitive MI again have $f S_{2}$ in the range 0.1 to 1 bar, as observed for the other volcanoes. The calculated $a_{\mathrm{FeS}}$ values are the highest of the four volcanoes, ranging from 0.1 up to 0.95 , or close to FeS saturation (fig. 4).

\section{Composition of fluids}

The compositions of fluids calculated for MI with known $\mathrm{H}_{2} \mathrm{O}, \mathrm{S}$ and $\mathrm{CO}_{2}$ contents are listed in table II together with input $f \mathrm{H}_{2}, f \mathrm{~S}_{2}$ and $f \mathrm{H}_{2} \mathrm{O}$ and the corresponding pressure of fluid saturation. In all cases, the computed mole fraction of $\mathrm{CH}_{4}$ is several orders of magnitude lower than that of either $\mathrm{CO}_{2}$ or $\mathrm{CO}$, and this species is not considered further in this work.

\subsection{Stromboli}

The pressures of fluid saturation of the MI in pumices range from 2100 bar to near 3500 bar (table II, fig. 8), i.e. they are comparable to those calculated by Métrich et al. (2001) and Bertagnini et al. (2003), despite the fact that sulphur bearing species were not taken into account in these works. This is due to the fact that, although melt sulphur contents are relatively high, the corresponding $f \mathrm{~S}_{2}$, and thus the molar abundances of S-bearing species, remain low. In the calculated examples, the mole fractions of $\mathrm{SO}_{2}+\mathrm{H}_{2} \mathrm{~S}$ never exceeds 0.1 (fig. 8). The mole fraction of $\mathrm{H}_{2} \mathrm{O}$ remains relatively constant, at about 0.3 , while that of $\mathrm{CO}_{2}$ slightly increases with pressure, exceeding 0.6 at near 3500 bar. The fluid coexisting with $\mathrm{MI}$ in scoria, calculated with the assumption of $50 \mathrm{ppm} \mathrm{CO}_{2}$ dissolved, corresponds to entrapement pressures of $100 \mathrm{bar}$, which is equivalent to a depth beneath the crater of $c a .300 \mathrm{~m}$, ie similar to previous estimates (e.g., Harris and Stevenson, 1997). Given that the central part of the volcano is permanently flushed with $\mathrm{CO}_{2}$ rich gases, as remote sensing of the volcanic plume indicates (Allard et al., 1994), it is unlikely that magmas stored in the shallow reservoir are $\mathrm{CO}_{2}$-free. Therefore the $50 \mathrm{ppm}$ threshold appears to a be a limiting condition which corresponds to the maximum possible pressure depth at which the upper reservoir that feeds the typical Strombolian activity is lying. Deeper conditions will inevitably produce $\mathrm{MI}$ with detectable $\mathrm{CO}_{2}$ contents with the FTIR method. Under these conditions it appears that the fluid phase is extremely rich in $\mathrm{CO}_{2}$, with $\mathrm{X}_{\mathrm{CO}_{2}}$ in excess of 0.9 (fig. 8). In contrast, the water content of the shallow magmatic fluid is very low being even lower than $\mathrm{SO}_{2}$ in some instances.

Figure 9 shows the evolution of both $\mathrm{H}_{2} \mathrm{O}$ / $/ \mathrm{SO}_{2 \text { tot }}$ and $\mathrm{CO}_{2} / \mathrm{SO}_{2 \text { tot }}\left(\mathrm{SO}_{2 \text { tot }}=\mathrm{SO}_{2}+\mathrm{H}_{2} \mathrm{~S}\right)$ mole ratios with pressure. MI of pumices define a broad positive trend in both ratios, whose extrapolation to near surface conditions corresponds to gases with $\mathrm{H}_{2} \mathrm{O} / \mathrm{SO}_{2 \text { tot }}$ and $\mathrm{CO}_{2} / \mathrm{SO}_{2 \text { tot }}$ ratios between 0.1 and 1 . Such ratios are at the lower end of the range displayed by fluids coexisting with scoria MI. In these, the $\mathrm{H}_{2} \mathrm{O} / \mathrm{SO}_{2}$ tot can exceed 10 while the $\mathrm{CO}_{2} / \mathrm{SO}_{2 \text { tot }}$ can go over 1000. Clearly such a large spread is chiefly due to the variable contents of sulphur dissolved in MI in scoria. The fact that the pumice MI trend intersects the lower end of the scoria trend suggests that this ratio range of $0.1-1$ represents the fluid compositions of magmas just injected in the upper reservoir, which have not yet undergone extensive volatile degassing associated to normal Strombolian activity. 


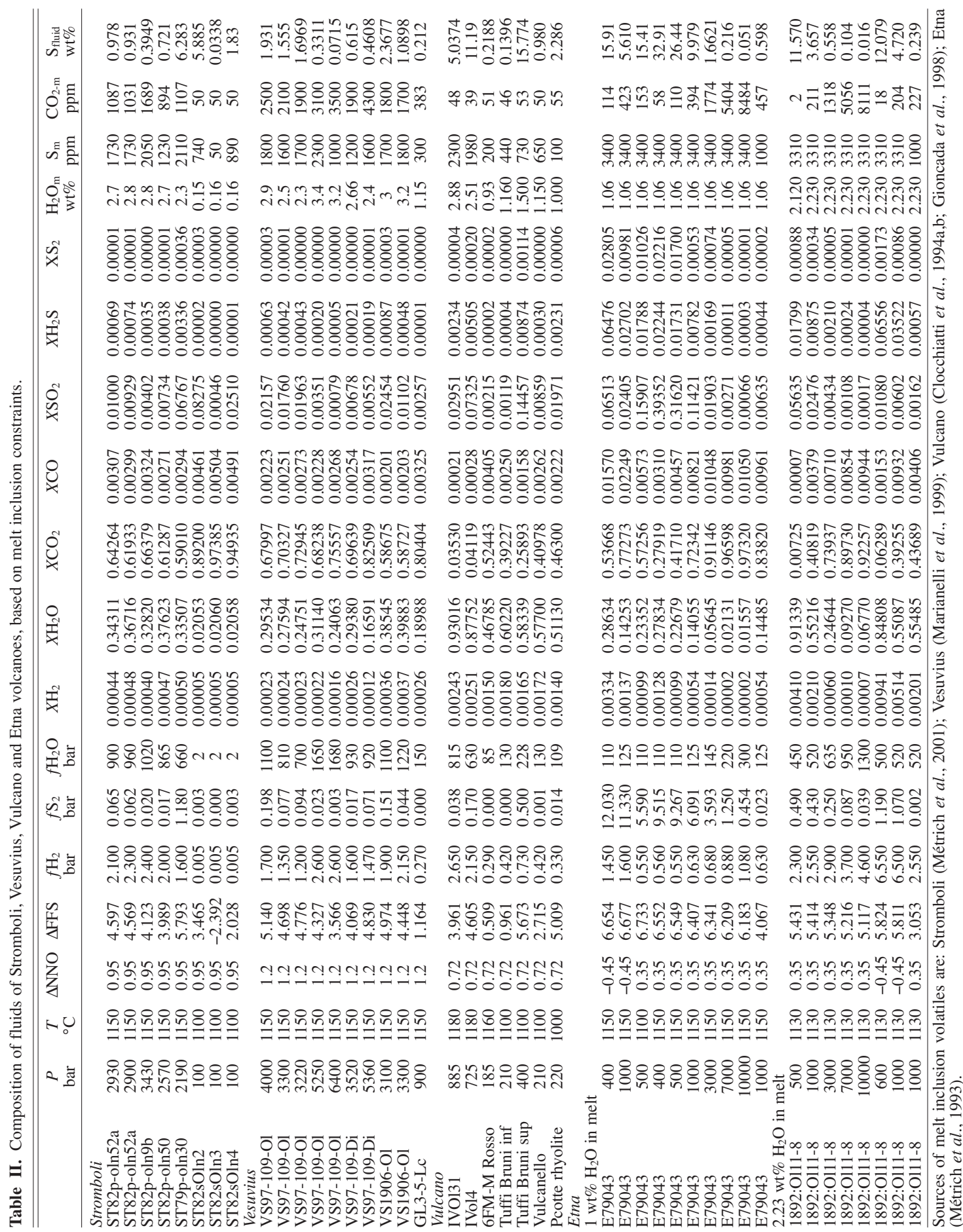




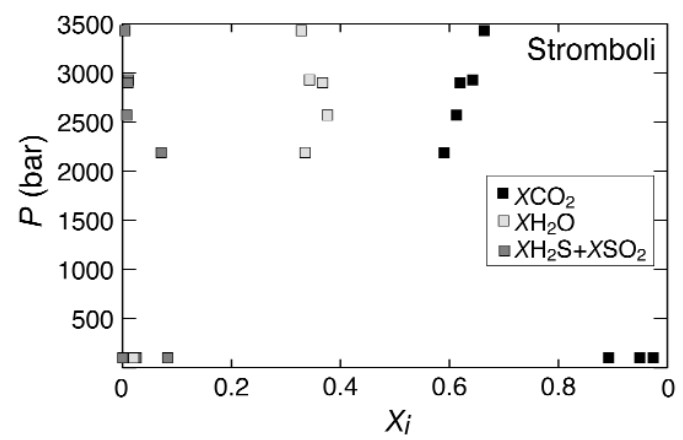

Fig. 8. Composition of fluids in equilibrium with melt inclusions from scoria and pumice (Métrich et al., 2001). $X_{i}$ is the mole fraction of species $i$. Symbols plotting at 100 bar correspond to melt inclusions in scoria, all other to melt inclusions in pumice. The compositions of fluids in scoria were calculated assuming a maximum $\mathrm{CO}_{2}$ content of $50 \mathrm{ppm}$.

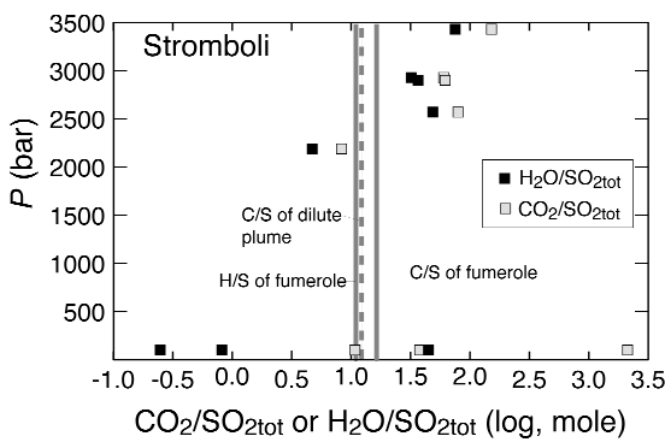

Fig. 9. Pressure evolution of $\mathrm{H}_{2} \mathrm{O} / \mathrm{SO}_{2}$ tot and $\mathrm{CO}_{2} /$ $/ \mathrm{SO}_{2 \text { tot }}$ mole ratios of fluids in equilibrium with melt inclusion of Stromboli melt inclusions. The thick grey continuous and dashed lines represent average $\mathrm{C} / \mathrm{S}$ and $\mathrm{H} / \mathrm{S}$ ratio measured on a hot fumerole or within the dilute plume at Stromboli (Allard et al., 1994).

\subsection{Vesuvius}

The mole fractions of $\mathrm{CO}_{2}, \mathrm{H}_{2} \mathrm{O}$ and $\mathrm{SO}_{2 \text { tot }}$ of the 1944 eruption are plotted against pressures of fluid saturation on fig. 10. Calculated pressures range from slightly below 1000 bar to over 6500 bar, being again similar to those cal- culated by Marianelli et al. (1999). There is no clear trend with pressure, but it is interesting to note that even relatively low pressure MI yield fluid compositions very rich in $\mathrm{CO}_{2}$. In all computed examples, the $\mathrm{SO}_{2}$ and $\mathrm{H}_{2} \mathrm{~S}$ mole fractions remain below 0.05 , whereas the mole fraction of $\mathrm{H}_{2} \mathrm{O}$ ranges betwen 0.2 up to 0.4 .

The $\mathrm{H}_{2} \mathrm{O} / \mathrm{SO}_{2 \text { tot }}$ and $\mathrm{CO}_{2} / \mathrm{SO}_{2 \text { tot }}$ mole ratios decrease with pressure down to values of about 20 and 50, respectively, at 3000 bar (fig. 11), and then increase again with further pressure decrease. The second part of the evolution remains hypothetical, however, since it is based on a single MI datum at 900 bar.

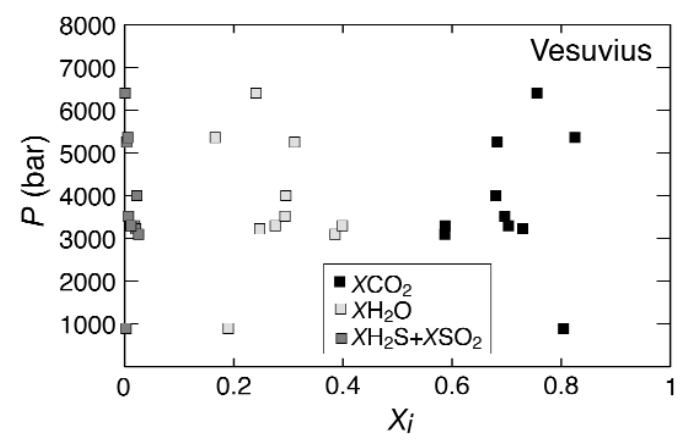

Fig. 10. Composition of fluids in equilibrium with melt inclusions of the 1944 Vesuvius eruption (Marianelli et al., 1999). $X_{i}$ is the mole fraction of species $i$. Note the rather constant fluid composition over the pressure interval.

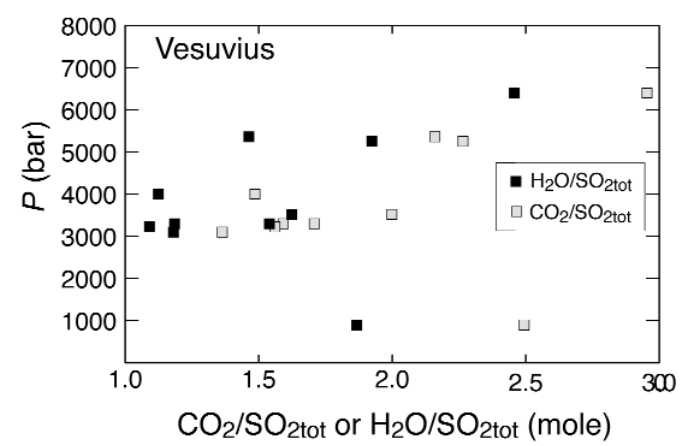

Fig. 11. Pressure evolution of $\mathrm{H}_{2} \mathrm{O} / \mathrm{SO}_{2 \text { tot }}$ and $\mathrm{CO}_{2} /$ $/ \mathrm{SO}_{2 \text { tot }}$ mole ratios of fluids in equilibrium with melt inclusion of the 1944 Vesuvius eruption. 


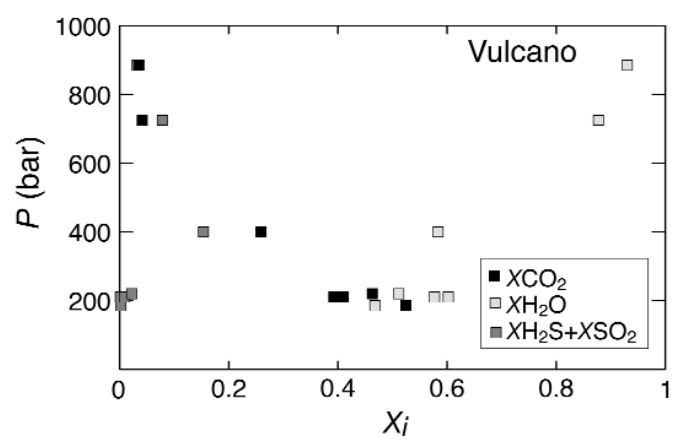

Fig. 12. Composition of fluids in equilibrium with melt inclusions of Vulcano magmas (Clocchiatti et al., 1994a,b; Gioncada et al., 1998). $X_{i}$ is the mole fraction of species $i$. Fluid compositions have been calculated assuming that the melt inclusions contain $50 \mathrm{ppm}$ dissolved $\mathrm{CO}_{2}$. This gives maximum $\mathrm{CO}_{2}$ contents of the fluid. Note the continuous evolution of the fluid composition with pressure.

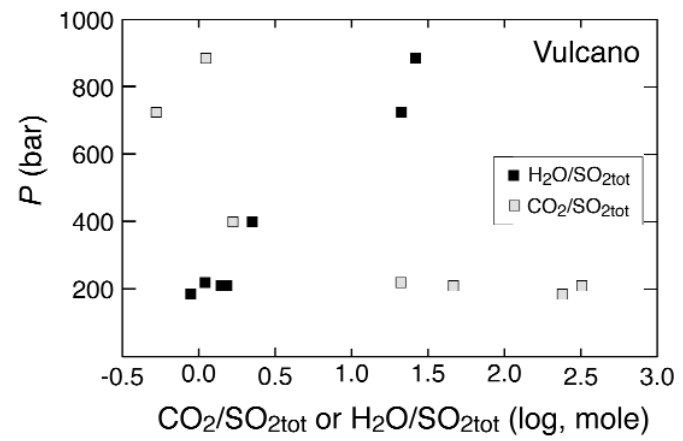

Fig. 13. Pressure evolution of $\mathrm{H}_{2} \mathrm{O} / \mathrm{SO}_{2}$ tot and $\mathrm{CO}_{2} /$ $/ \mathrm{SO}_{2 \text { tot }}$ mole ratios of fluids in equilibrium with melt inclusions of Vulcano magmas.

\subsection{Vulcano}

The fluid composition of Vulcano magmas is shown in fig. 12. Given the lack of detectable $\mathrm{CO}_{2}$, and the generally low melt $\mathrm{H}_{2} \mathrm{O}$ contents $(<3 \mathrm{wt} \%)$, the calculated pressures for fluid saturation are low compared to Stromboli and Vesuvius, ranging from 900 down to 200 bar, in agreement with previous findings (Clocchiatti et al., 1994a; Gioncada et al., 1998). The data set shows a regular variation of fluid composition as pressure decreases. Between 900 and 200 bar, the mole fraction of $\mathrm{H}_{2} \mathrm{O}$ decreases continuously, from over 0.9 down to 0.5 , being paralleled by a concomitant increase in $\mathrm{CO}_{2}$. The mole fraction of $\mathrm{SO}_{2 \text { tot }}$ first increases up to $400 \mathrm{bar}$, where it reaches a value of 0.15 , and then decreases down to 0.05 at 200 bar.

The evolution of the $\mathrm{H}_{2} \mathrm{O} / \mathrm{CO}_{2}$ tot and $\mathrm{CO}_{2} /$ $/ \mathrm{SO}_{2 \text { tot }}$ mole ratios with pressure is shown on fig. 13. The $\mathrm{H}_{2} \mathrm{O} / \mathrm{CO}_{2 \text { tot }}$ decreases continuously with pressure, reaching values of 1 at 200 bar. In contrast, the $\mathrm{CO}_{2} / \mathrm{SO}_{2 \text { tot }}$ ratio increases with decreasing pressures, from 1 at 900 bar up to 400 at 200 bar: note that this ratio displays considerable variation at 200 bar, as observed for Stromboli. This reflects variable depletion of sulphur during shallow level degassing of the magmas

\subsection{Etna}

Figure 14 shows the evolution of the mole fractions of $\mathrm{H}_{2} \mathrm{O}, \mathrm{CO}_{2}$ and $\mathrm{S}_{\text {tot }}$ with pressure calculated for melt water contents of 1 and 2.23 $\mathrm{wt} \%, \mathrm{fO}_{2}$ at $\mathrm{NNO}+0.35$, and melt sulphur contents of 3300-3400 ppm. We stress again that calculations assume the presence of a fluid phase in the entire pressure range. In both cases, the fluid composition is dominated by $\mathrm{CO}_{2}$ at pressures higher than 2000 bar. At pressures higher than 7000 bar, the fluid consists of more than $90 \%$ of $\mathrm{CO}_{2}$. For instance at 10000 bar, the calculated fluid composition corresponding to 1 wt $\%$ dissolved $\mathrm{H}_{2} \mathrm{O}$ has a mole fraction of $\mathrm{CO}_{2}$ of 0.97 , that is the fluid is nearly pure $\mathrm{CO}_{2}$, in agreement with fluid inclusion constraints on primitive Etna basalts (Clocchiatti et al., 1992). Under such conditions the calculated $\mathrm{CO}_{2}$ content of the basalt melt is $0.85 \mathrm{wt} \%$ (table II). It is only below 1000 bar $\left(2.23 \mathrm{wt} \% \mathrm{H}_{2} \mathrm{O}\right)$ or 400 bar $\left(1 \mathrm{wt} \% \mathrm{H}_{2} \mathrm{O}\right)$ that $\mathrm{CO}_{2}$ is lower than $\mathrm{H}_{2} \mathrm{O}$. For water-rich conditions, the mole fraction of $\mathrm{H}_{2} \mathrm{O}$ always exceeds that of $\mathrm{SO}_{2 \text { tot }}$, while at a melt $\mathrm{H}_{2} \mathrm{O}$ content of $1 \mathrm{wt} \%, \mathrm{SO}_{2 \text { tot }}$ equals or even exceeds $\mathrm{H}_{2} \mathrm{O}$ at pressures lower than 500 bar.

The difference in fluid composition arising from different melt $\mathrm{H}_{2} \mathrm{O}$ contents is illustrated on fig. 15 where the mole fraction of $\mathrm{H}_{2} \mathrm{O}$ is plotted 
against that of $\mathrm{CO}_{2}$. Note that the mole fractions plotted correspond to actual value that take into account the sulphur species, whose total mole fraction reach values in excess of 0.44 (fig. $14 \mathrm{a}, \mathrm{b}$, table II). This is why all the data plot below the mixing line corresponding to a binary $\mathrm{H}_{2} \mathrm{O}-\mathrm{CO}_{2}$. Clearly, the amount of dissolved water significantly affects the fluid composition: at 500 bar the calculated mole fraction of $\mathrm{H}_{2} \mathrm{O}$ varies from 0.92 for a melt $\mathrm{H}_{2} \mathrm{O}$ content of 2.2 wt $\%$, down to 0.22 for a melt $\mathrm{H}_{2} \mathrm{O}$ content of 1 wt $\%$. However, the effect of melt $\mathrm{H}_{2} \mathrm{O}$ content vanishes at high pressure, so that at or above 7000 bar, the calculated fluid compositions for the two melt water contents diverge by less than 0.05 in their mole fraction of $\mathrm{H}_{2} \mathrm{O}$. Variation in $f \mathrm{O}_{2}$ in the range considered, does not strongly
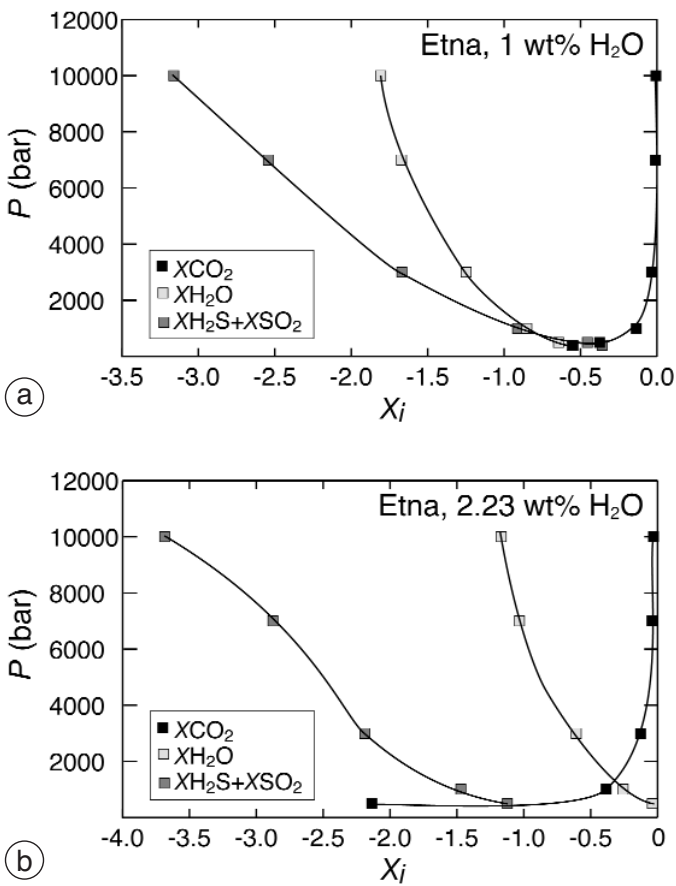

Fig. 14a,b. Evolution of the mole fractions of $\mathrm{H}_{2} \mathrm{O}$, $\mathrm{CO}_{2}$ and $\mathrm{H}_{2} \mathrm{~S}+\mathrm{SO}_{2}$ with pressure calculated for melt water contents of 1 (a) and 2.23 (b) $\mathrm{wt} \%, \mathrm{fO}_{2}$ at $\mathrm{NNO}+0.35$, and melt sulphur contents of 3300-3400 ppm, corresponding to primitive Etnaean magmas. $X_{i}$ is the mole fraction of species $i$.

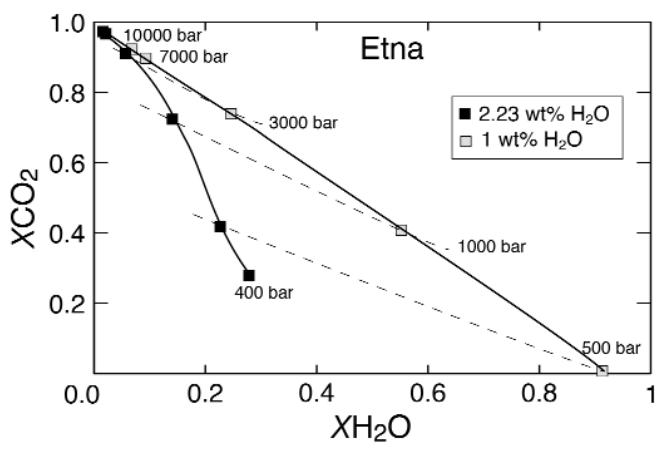

Fig. 15. Evolution of the mole fraction of $\mathrm{H}_{2} \mathrm{O}$ against that of $\mathrm{CO}_{2}$ calculated for melt water contents of 1 and $2.23 \mathrm{wt} \%, f \mathrm{O}_{2}$ at $\mathrm{NNO}+0.35$, and melt sulphur contents of $3300-3400 \mathrm{ppm}$, corresponding to primitive Etnaean magmas. The mole fractions correspond to actual values, that take into account the sulphur species, whose total mole fraction reach values in excess of 0.44 (fig. 14a,b, table II). This is why all the data plot below a mixing line corresponding to a binary $\mathrm{H}_{2} \mathrm{O}-\mathrm{CO}_{2}$. Dashed lines represent isobaric conditions calculated for different melt water contents.

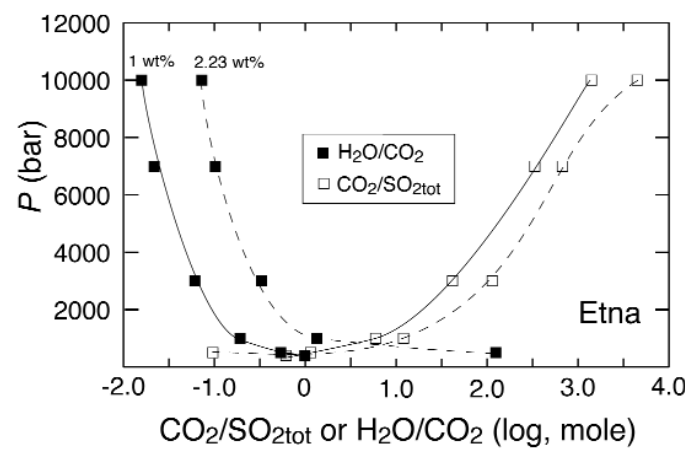

Fig. 16. Pressure evolution of the $\mathrm{H}_{2} \mathrm{O} / \mathrm{CO}_{2}$ and $\mathrm{CO}_{2} / \mathrm{SO}_{2 \text { tot }}$ mole ratios for melts having either 1 or $2.23 \mathrm{wt} \%$ dissolved $\mathrm{H}_{2} \mathrm{O}$ and $3300-3400 \mathrm{ppm}$ of dissolved sulphur at $\mathrm{NNO}+0.35$.

affect the fluid compositions, apart from the $\mathrm{SO}_{2} / \mathrm{H}_{2} \mathrm{~S}$ ratio. In contrast, a lower sulphur content of the melt (that is lower $f \mathrm{~S}_{2}$ ) obviously decreases significantly the abundances of sulphur bearing species and, by implication, increases the $\mathrm{CO}_{2} / \mathrm{SO}_{2}$ ratio (table II). 
Figure 16 shows the dramatic effect that pressure exerts on the $\mathrm{H}_{2} \mathrm{O} / \mathrm{CO}_{2}$ and $\mathrm{CO}_{2} / \mathrm{SO}_{2 \text { tot }}$ mole ratios. The $\mathrm{H}_{2} \mathrm{O} / \mathrm{CO}_{2}$ ratio increases from $0.01-0.1$ at 10000 bar to $1-100$ at $400-500$ bar, whereas the $\mathrm{CO}_{2} / \mathrm{SO}_{2 \text { tot }}$ decreases within this pressure interval from 1000 at 10000 bar down to $0.8-0.1$ at $400-500$ bar. The variation in melt water contents affects the $\mathrm{H}_{2} \mathrm{O} / \mathrm{CO}_{2}$ ratio more than the $\mathrm{CO}_{2} / \mathrm{SO}_{2 \text { tot }}$ one, and the latter should be more accurate if used for barometric purposes (i.e. depth of main stage of volatile exsolution, see below).

\section{Comparison with volcanic gases}

The comparison with volcanic gases can be only made for Stromboli, Vulcano and Etna, since hot fumaroles or volcanic plumes have not been emitted at Vesuvius since its last eruption in 1944.

\subsection{Stromboli}

For Stromboli, direct sampling of fumeroles in the vent is prevented by hazardous access (Allard et al., 1994). The hottest fumerole sampled had a temperature of $410^{\circ} \mathrm{C}$ which is $700^{\circ} \mathrm{C}$ lower than the estimated temperature of magma last equilibration in the shallow reservoir. This fumerole has a $\mathrm{H}_{2} \mathrm{O} / \mathrm{SO}_{2}$ mole ratio of 11 and a $\mathrm{CO}_{2} / \mathrm{SO}_{2}$ ratio of 19 . Both ratios fall within the range calculated for magmatic fluids in the shallow reservoir (fig. 9) and are thus compatible with an origin from such a depth. The average ratio of $\mathrm{CO}_{2} / \mathrm{SO}_{2}$ in the dilute plume is 11 , which fits also with a shallow reservoir origin, being at the lower end of the calculated fluid composition at 100 bar. The above reasoning, however, implicitly assumes that the volcanic plume composition is dominated by the composition of fluids at depth, and ignores the possible contribution of the melt degassing during ascent from the deep/shallow reservoirs to the surface. In other words, it assumes that the volcanic plume (or hot fumeroles) is fed by bubbles that escape the magma at a certain depth, reaching the surface unmodified (equivalent to a single step degassing at depth under closed system condi- tions). In the present case, this depth could lie anywhere between 100 and 3000 bar, since in this pressure range magmatic fluids having a $\mathrm{CO}_{2} / \mathrm{SO}_{2}$ ratio of 10 can be produced. Although such a scenario can apply to a magma intrusion at rest, like during periods of quiescent degassing with no magma emission, this is unlikely to happen in a decompressing magma body, in view of the exceedingly low melt viscosity of hydrous basalts that should allow volatiles degassing, and continuous melt-fluid re-equilibration, even on the short time scales characteristic of Strombolian eruptions.

We have thus calculated the bulk fluid composition arising from melt+fluid contribution, for various melt/fluid ratios, assuming that the melt can fully degass upon eruption or ascent (see also Scaillet and Pichavant, 2003). Figure 17 shows the results in terms of $\mathrm{CO}_{2} / \mathrm{SO}_{2}$ mole ratios, which is a ratio typically measured in volcanic plumes (Allard et al., 1994). Also shown are the $\mathrm{CO}_{2} / \mathrm{SO}_{2}$ mole ratios of the melt and fluid phases. Excluding kinetic effects, any fluid vented at Stromboli must lie between

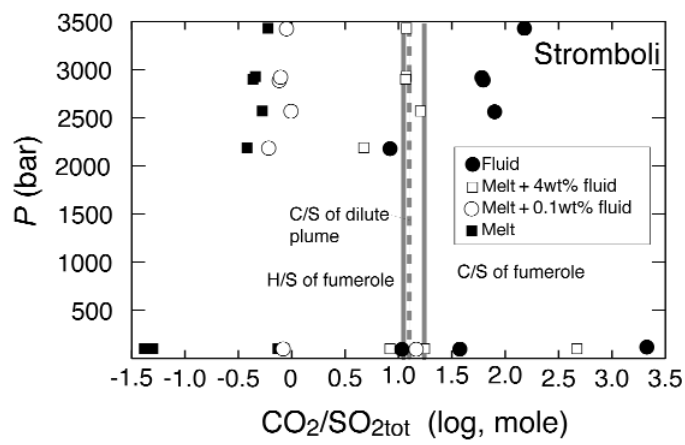

Fig. 17. Effect of the amount of fluid in the reservoir on the final fluid compositions (resulting from the contribution of volatiles from the melt and fluid, melt+fluid), expressed in terms of the $\mathrm{CO}_{2} / \mathrm{SO}_{2 \text { tot }}$ mole ratio (see text), for Stromboli magmas. The compositions of fluid and melt phases are shown as closed symbols. A fluid amount of $0.1 \mathrm{wt} \%$ in the deep reservoir results in a final fluid having a $\mathrm{CO}_{2} / \mathrm{SO}_{2 \text { tot }}$ ratio of 1 , whereas an amount of $4 \mathrm{wt} \%$ results in a final $\mathrm{CO}_{2} / \mathrm{SO}_{2 \text { tot }}$ mole ratio of 10 , similar to that measured in the volcanic plume of Stromboli (thick grey line, from Allard et al., 1994). 
these two poles. As shown on fig. 17, if the deep magma contains $0.1 \mathrm{wt} \%$, the resulting bulk fluid has a $\mathrm{CO}_{2} / \mathrm{SO}_{2}$ ratio of 1 , ie significantly lower than the average one measured in the plume (11). In contrast, if the magma at depth contains $4 \mathrm{wt} \%$ fluid, then the resulting $\mathrm{CO}_{2} / \mathrm{SO}_{2}$ ratio is similar to that measured, with an average at 11 . Higher fluid contents at depth would further increase the ratio: a fluid content of $10 \mathrm{wt} \%$ would give a $\mathrm{CO}_{2} / \mathrm{SO}_{2}$ ratio of 22 . We thus suggest that in order to produce a volcanic plume with a $\mathrm{CO}_{2} / \mathrm{SO}_{2}$ ratio of 11 , the main magma reservoir must be fluid-saturated with a fluid amount of $c a .4 \mathrm{wt} \%$.

Petrological and geophysical data (see Francalanci et al., 1989) suggest the existence of a large reservoir at $10-14 \mathrm{~km}$ depth, in agreement with MI constraints (Métrich et al., 2001; Bertagnini et al., 2003), in which the magmas injected in the shallow reservoir are produced. On this basis, it is probable that such a reservoir is the major source of volatile emissions at Stromboli (Bertagnini et al., 2003). Thus, the above analysis suggests that such a reservoir must contain a significant amount of free fluid in order to reconcile observations (volcanic plume composition, MI volatile contents) and the thermodynamic constraints (this work) on fluid composition. The total volatile content of Strombolian magmas can be estimated using the fluid composition calculated in this work, the amount of volatiles dissolved in the melt (Métrich et al., 2001) and assuming a fluid content of $4 \mathrm{wt} \%$. This gives the following range (corresponding to different volatile contents of $\mathrm{MI}$ in pumice): $\mathrm{H}_{2} \mathrm{O}_{\text {tot }}: 2.86-3.45$ wt $\%$; $\mathrm{CO}_{2 \text { tot }}: 2.94-3.46 \mathrm{wt} \%$; $\mathrm{SO}_{2 \text { tot }}: 0.29-0.90$ wt $\%$ (or 1450-4500 ppm sulphur). The $\mathrm{H}_{2} \mathrm{O}$ and $\mathrm{S}$ values are close to those analysed in $\mathrm{MI}$, which is due to the fact that the concentrations of both volatiles are comparable in melt and fluid. In contrast, the bulk $\mathrm{CO}_{2}$ content is more than one order of magnitude higher than that dissolved in MI (0.089-0.169 wt\%), which is due to the $\mathrm{CO}_{2}$-rich character $\left(\mathrm{XCO}_{2}>0.6\right)$ of the fluid phase at Stromboli. The very high bulk $\mathrm{CO}_{2}$ content suggests that even the most primitive magmas at Stromboli, i.e. those generated at mantle pressures, are fluid-saturated as well.

\subsection{Vulcano}

The geochemistry of volcanic fumeroles at Vulcano has been extensively discussed and modelled using various approaches and chemical tracers (e.g., Capasso et al., 1994, 2001; Chiodini et al., 1995; Todesco, 1997; Nuccio et al., 1999; Giggenbach et al., 2001; Nuccio and Paonita, 2001; Di Liberto et al., 2002; Diliberto et al., 2002; Paonita et al., 2002). There is a general agreement that the fumerole compositions at Vulcano result from mixing between a magmatic source and a boiling hydrothermal system. Here we focus on the highest temperature fumeroles, in which the magmatic signature is less likely to be affected by such a mixing. The hottest fumeroles reached a temperature of near $700^{\circ} \mathrm{C}$, and consisted in $85-90 \% \mathrm{H}_{2} \mathrm{O}, 5-15 \%$ $\mathrm{CO}_{2}$ with minor amounts of sulphur, in the order of $3 \%$ (Capasso et al., 1994), having an $\mathrm{fO}_{2}$ of $\mathrm{NNO}+1$ or very close to that inferred from sulphur speciation $(\mathrm{NNO}+0.72)$. Although quite variable, the measured $\mathrm{CO}_{2} / \mathrm{SO}_{2}$ mole ratio is ca. 10 (e.g., Giggenbach et al., 2001), or similar to that of Stromboli. If taken at face value, the 9/1 ratio of $\mathrm{H}_{2} \mathrm{O} / \mathrm{CO}_{2}$ suggests an origin of such fluids from a reservoir located at 800-900 bar (fig. 12), since lower pressure would correspond to higher mole fraction of $\mathrm{CO}_{2}$. It must be remembered, however, that this is based on the assumption that MI at Vulcano have a maximum of $50 \mathrm{ppm}$ dissolved $\mathrm{CO}_{2}$. Clearly, lower dissolved $\mathrm{CO}_{2}$ would allow water-rich fluids to be produced at lower pressures. However, geochemical modelling (Nuccio et al., 1999) has shown that the hydrothermal contribution is quite high even in the hottest fumeroles (up to $30 \%$ ), which implies that the $\mathrm{H}_{2} \mathrm{O}$ mole fraction of fumeroles are probably maximum values. Similarly, if the $\mathrm{CO}_{2} / \mathrm{SO}_{2}$ ratio is used to infer the depth of fluid exsolution, then a pressure of 200-300 bar is retrieved (fig. 13), but again, lower $\mathrm{CO}_{2}$ in $\mathrm{MI}$ would decrease this estimate. On the other hand, magmatic gas scrubbing by aquifers is known to strongly deplete magmatic gases of their $\mathrm{SO}_{2}$ (Symonds et al., 2001) which indicates that the sulphur content of fumeroles are minimum values. This will counteract the effect due to an overestimation of $\mathrm{CO}_{2}$ in $\mathrm{MI}$, leading to an increase in the $\mathrm{CO}_{2} / \mathrm{SO}_{2}$ ratio. 
As for Stromboli, the above comparison ignores the melt contribution to the volatile budget and that due to decompression or to crystallisation. However, compared to Stromboli, a proper evaluation of this contribution is hampered by the compositional variability of erupted magmas at Vulcano (e.g., Clocchiatti et al., 1994a). That is, the evaluation of melt contribution depends on whether the upper reservoir stores rhyolite or some more mafic composition. If for instance, we assume that the main degassing magmatic source is rhyolite melt, then a fluid amount of 0.5 $\mathrm{wt} \%$ in the shallow reservoir would be needed in order to release a fluid with appropriate mole ratios of $\mathrm{H}_{2} \mathrm{O} / \mathrm{CO}_{2}$ and $\mathrm{CO}_{2} / \mathrm{SO}_{2}$. Clearly, however, the uncertainty concerning the chemical nature of the plumbing system, coupled with the lack of precise $\mathrm{CO}_{2}$ determination in MI, prevent us obtaining robust constraints on bulk volatile compositions and their possible depth of exsolution. To these sources of error must be added the hydrothermal contribution, that modifies to various extents the composition of magmatic fluids (Nuccio et al., 1999). We must therefore await for more precise data on $\mathrm{CO}_{2}$ content in $\mathrm{MI}$ before doing any conclusive statement.

\subsection{Etna}

Although we lack $\mathrm{CO}_{2}$ constraints in $\mathrm{MI}$, the case for Etna is made simpler than that of Vulcano, because of the chemical homogeneity of magmas erupted and because the numerous eruptions since 1970 have allowed continuous monitoring of the volcanic plume for $\mathrm{CO}_{2}$ and $\mathrm{SO}_{2}$ species, among other volatiles, using modern analytical tools. In addition, contrary to the two previous volcanoes, there is at least one complete data set of hot gas composition available for the 1970 eruption (Hundington, 1973; Gerlach, 1980). The temperature of gas collection $\left(1075^{\circ} \mathrm{C}\right)$ is virtually identical to that of magma extrusion which greatly facilitates the comparison with the thermodynamic calculation performed here, since it can be anticipated that the magmatic component in these gases is largely dominant. We first consider this data set and then compare our calculations with remote sensing results. As for Stromboli and Vulcano, we start by assuming that fluids correspond to deep exsolution of a stagnant magma body and then we evaluate the effect of melt contribution arising during decompression.

The average composition of volcanic gases sampled by Huntingdon (1973) and restored by Gerlach (1980) (excluding the extremes), reads as (in mole fraction): $\mathrm{H}_{2} \mathrm{O}=0.48 \pm 0.03 ; \mathrm{CO}_{2}=$ $=0.24 \pm 0.05$, and $\mathrm{SO}_{2}=0.26 \pm 0.05 \quad(n=14)$. A remarkable feature of this composition is its very high $\mathrm{SO}_{2}$ content, that equals or even exceeds $\mathrm{CO}_{2}$, underscoring the potential of Etnean magmas to release sulphur-rich fluids. Inspection of fig. 14a,b shows that production of such a fluid requires both relatively low melt $\mathrm{H}_{2} \mathrm{O}$ contents and low pressure conditions, essentially below 1000 bar. Fluids equilibrated with a melt $\mathrm{H}_{2} \mathrm{O}$ content of $2.23 \mathrm{wt} \%$, reach a maximum mole fraction of $\mathrm{SO}_{2}$ below $10 \%$, and are thus unlikely to be the source of gases sampled in 1970. In contrast, at a melt $\mathrm{H}_{2} \mathrm{O}$ content of 1 wt $\%$, sulphur-rich gas compositions can be produced at pressures below 1000 bar: the fluid composition calculated at 400 bar (table II) closely approaches the gases measured by Huntingdon (1973) which in turn suggests that those gases could have been released from a magma body lying at such a depth.

The 1970 data set of gas compositions is unique, and for more recent times information on the chemical composition of volcanic gases has been obtained mostly via remote sensing of volcanic plumes or through analyses of diffuse and peripheral gas emissions (e.g., Allard et al., 1991; Bruno et al., 1999, 2001). However, Allard et al. (1991) report a $\mathrm{CO}_{2} / \mathrm{SO}_{2}$ mole ratio of ca. 10 measured in hot $\left(1090^{\circ} \mathrm{C}\right)$ crater gases during the 1986 eruption, which is significantly higher than that measured in the 1973 eruption (Hundington, 1973; Gerlach, 1980). The $\mathrm{CO}_{2} /$ $/ \mathrm{SO}_{2}$ ratio measured in the summit crater plume ranges from 10 to as high as 38, but Allard et al. (1991) consider the lower value as more representative of the average gas output. Such a ratio is attained at around 1000 bar for a melt $\mathrm{H}_{2} \mathrm{O}$ content of $2.23 \mathrm{wt} \%$, and at slightly higher pressures for $1 \mathrm{wt} \% \mathrm{H}_{2} \mathrm{O}$ dissolved in melt, around 1500 bar. The full compositional data corresponding to these gases are not known, in particular the mole fraction of $\mathrm{H}_{2} \mathrm{O}$ and $\mathrm{SO}_{2}$, 
which prevents from further constraining the depth of degassing.

We now consider the melt contribution. Figure $18 \mathrm{a}, \mathrm{b}$ displays the $\mathrm{CO}_{2} / \mathrm{SO}_{2}$ mole ratio of the bulk fluid released during decompression of a magma containing either 1 or $5 \mathrm{wt} \%$ fluid, for a variety of starting pressures, in the interval 400-10000 bar. Also shown are the $\mathrm{CO}_{2} / \mathrm{SO}_{2}$
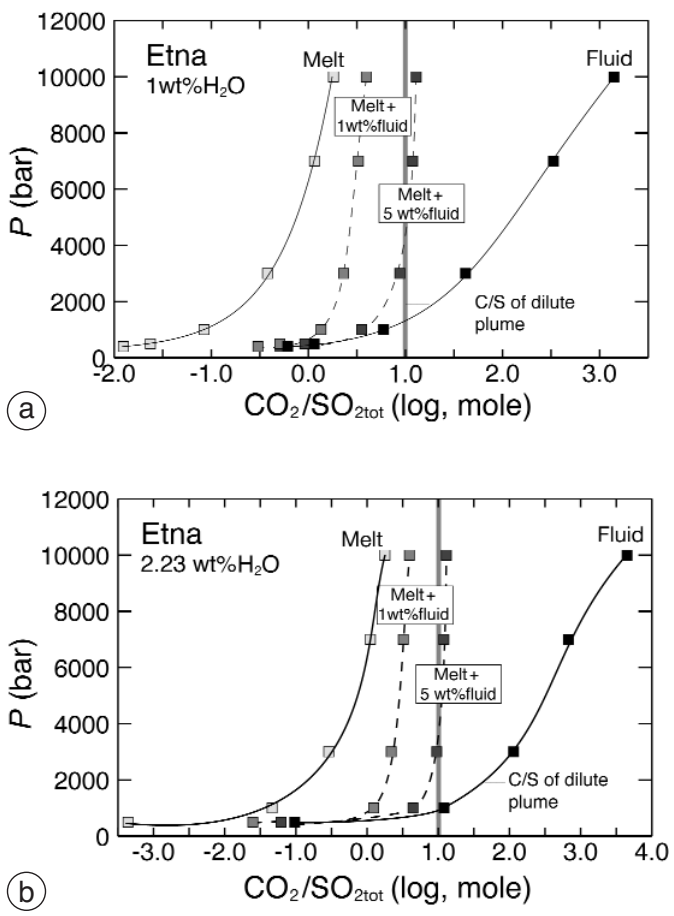

Fig. 18a,b. Effect of the amount of fluid in the reservoir on the final fluid compositions (resulting from the contribution of volatiles from the melt and fluid, melt+fluid), expressed in terms of $\mathrm{CO}_{2} / \mathrm{SO}_{2}$ tot mole ratio (see text). Calculations were done for melt $\mathrm{H}_{2} \mathrm{O}$ contents of 1 (a) and 2.23 (b) wt $\%, 3300-3400$ ppm dissolved sulphur, $\mathrm{NNO}+0.35$, which should correspond to primitive Etnaean magmas. An amount of $1 \mathrm{wt} \%$ fluid in the deep reservoir results in a final fluid having a $\mathrm{CO}_{2} / \mathrm{SO}_{2 \text { tot }}$ ratio of 2-3. In contrast, for magmas stored at pressures higher than 2000 bar, an amount of $5 \mathrm{wt} \%$ results in a final fluid $\mathrm{CO}_{2} / \mathrm{SO}_{2 \text { tot }}$ ratio of 10 upon near surface degassing, similar to that measured in the volcanic plume at Etna (thick grey line Allard et al., 1991). mole ratios corresponding to the melt and fluid phases, calculated at the corresponding pressures. The calculations were done for melt $\mathrm{H}_{2} \mathrm{O}$ contents of 1 and 2.23 wt\% having 3300-3400 ppm sulphur dissolved. Both melt $\mathrm{H}_{2} \mathrm{O}$ contents yield similar results, however (fig. 18a,b). Under such conditions, the simulations show that any magma having $1 \mathrm{wt} \%$ fluid at any depth falls short in producing a bulk fluid having the observed $\mathrm{CO}_{2} / \mathrm{SO}_{2}$ ratio of 10 , the computed values being in the order of 2-3 at best. In contrast, if the magma has an amount of fluid of 5 $\mathrm{wt} \%$ and is stored at a depth higher than 3000 bar, then its decompression to near atmospheric conditions should release a fluid having the appropriate $\mathrm{CO}_{2} / \mathrm{SO}_{2}$ mole ratio. It is interesting to note that beyond 3000 bar, the curves are very steep, illustrating that the calculation is insensitive to the choice of the starting pressure. Also noteworthty is the fact that at pressures below 2000 bar, the $\mathrm{CO}_{2} / \mathrm{SO}_{2}$ ratio sharply decreases as pressure decreases, such that magmas stored at 400-500 bar with fluids amount of 1-5 wt $\%$ would release fluids with $\mathrm{CO}_{2} / \mathrm{SO}_{2}$ ratios lower than 1, or unlike those measured in the volcanic plume.

The previous calculation assumes obviously that the rising magma exsolves continuously its volatiles but that those volatiles do not escape the parent magma until near atmospheric conditions are attained (i.e. a closed system assumption). In other words this corresponds to the case where the differential ascent velocities of a rising magma batch and its exsolved bubbles are negligible. Given the low viscosity of hydrous basalt melt and the significant proportion of fluid inferred (which should correspond to a large volume fraction of bubbles in the magma, see Vergniolle and Jaupart, 1986 ), this assumption is clearly questionable. Yet, progressive escape of bubbles at high pressure would deplete the magma in $\mathrm{CO}_{2}$ relative to sulphur, since the $\mathrm{CO}_{2} / \mathrm{SO}_{2}$ ratio of the fluid is always much higher than 1 at pressures higher than 500 bar ( fig. $18 \mathrm{a}, \mathrm{b})$. Early depletion of a $\mathrm{CO}_{2}$-rich gas phase (i.e. open system) would therefore lead to a significant decrease in the final bulk $\mathrm{CO}_{2} / \mathrm{SO}_{2}$ ratio produced by the degassing lava. We therefore conclude that the fluid amounts derived above can be considered minimum estimates. 
If the measured $\mathrm{CO}_{2} / \mathrm{SO}_{2}$ ratio measured in the volcanic plume or hot fumeroles is indeed representative of magmatic conditions at depth and correspond to full degassing of either outpoured lava or crystallising magma, we can use the above results to infer the bulk volatile content of the magma. To do so we first consider that the main reservoir feeding the Etna eruption lies at 3000 bar, in accordance with the geophysic, geodetic, petrological and geochemical evidence summarised previously. For a reservoir at 3000 bar storing a magma with $1 \mathrm{wt} \%$ dissolved $\mathrm{H}_{2} \mathrm{O}$ and coexisting with $5 \mathrm{wt} \%$ fluid the bulk volatile content is: $\mathrm{H}_{2} \mathrm{O}_{\mathrm{tot}}=1.05 \mathrm{wt} \%, \mathrm{CO}_{2 \mathrm{tot}}=4.89 \mathrm{wt} \%$, $\mathrm{SO}_{2 \text { tot }}=0.81 \mathrm{wt} \%$. For a magma with $2.23 \mathrm{wt} \%$ dissolved $\mathrm{H}_{2} \mathrm{O}$, the figures are: $\mathrm{H}_{2} \mathrm{O}_{\text {tot }}=2.70$ $\mathrm{wt} \%, \mathrm{CO}_{2 \text { tot }}=4.48 \mathrm{wt} \%, \mathrm{SO}_{2 \text { tot }}=0.68 \mathrm{wt} \%$. A reservoir at 1000 bar with a magma at $1 \mathrm{wt} \%$ $\mathrm{H}_{2} \mathrm{O}$ in melt would lead to: $\mathrm{H}_{2} \mathrm{O}_{\text {tot }}=1.31 \mathrm{wt} \%$, $\mathrm{CO}_{2 \text { tot }}=3.81 \mathrm{wt} \%, \mathrm{SO}_{2 \text { tot }}=1.57 \mathrm{wt} \%$, that is a lower pressure increases both $\mathrm{H}_{2} \mathrm{O}$ and $\mathrm{SO}_{2}$ yields relative to $\mathrm{CO}_{2}$. The bulk content calculated for $\mathrm{H}_{2} \mathrm{O}$ does not depart significantly from that in MI, whereas the bulk contents of $\mathrm{CO}_{2}$ and $\mathrm{SO}_{2}$ are considerably higher than the amounts dissolved in the melt (see table II).

In summary, it appears that the gas compositions measured at Etna can be produced in a variety of ways which somehow reflect the complexity and large vertical extent of the plumbing system of the volcano. In particular, the existence of several levels of magma storage in the crust is likely to induce a variety of fluid composition since the pressure of gas release may exert a strong control on its composition (e.g., Caracausi et al., 2003; this work). There are no reasons magmas erupted at Etna over the last decades should have all followed the same ascent path and ponded at constant storage levels. The difference in the $\mathrm{CO}_{2} / \mathrm{SO}_{2}$ ratios between the 1970 gases and those emitted during the 1975-1995 period may be a reflection of the complex feeding system. The 1970 gas composition can be reproduced by storage and degassing at 400 bar of a relatively water-poor but sulphur-rich magma. In contrast, gases emitted in more recent eruptions require storage at slightly greater depths, around 1000-1500 bar, if they were expelled from this level with no further melt contribution. If melt accompanied gas escape, then the source was more likely at 3000 bar and filled with relatively undegassed magma (sulphur-rich), coexisting with a significant amount of fluid in order to yield a volcanic plume with an average $\mathrm{CO}_{2} / \mathrm{SO}_{2}$ ratio of about 10 . These are not the only possibilities, however. It could be considered that the magma strored at 3000 bar contained only $1000 \mathrm{ppm}$ dissolved sulphur, which would increase the $\mathrm{CO}_{2} / \mathrm{SO}_{2}$ ratio (table II). The only way to distinguish between these different scenarii is to have a combined $\mathrm{H}_{2} \mathrm{O}-\mathrm{S}$ $\mathrm{CO}_{2}$ data set on $\mathrm{MI}$, as well as a more detailed knowledge about the possible variation of preeruptive melt $\mathrm{H}_{2} \mathrm{O}$ contents between eruptive events.

\section{Discussion and conclusions}

The empirical model presented in this study has allowed us to calculate the sulphur fugacities of hydrous basaltic magmas. There is little control, however, on the values retrieved since even at near surface conditions, $f \mathrm{~S}_{2}$ is a rarely measured parameter in volcanic gases. Pioneering attemps of Sato and Moore (1973) on the 1970 Etna gases failed to measure the $f S_{2}$ of the hottest gases emitted and they could only obtain data up to $860^{\circ} \mathrm{C}$. Yet, as Gerlach (1980) has shown, the $f \mathrm{~S}_{2}$ measured fits in with that restored from gas composition and thus with our own calculation. Apart from this case, however, we are left to accept the calculated values at face value, until experimental data on the relationships between $f S_{2}$ and sulphur solubility in hydrous mafic melts become available.

We have seen that the knowledge of $f \mathrm{~S}_{2}, f \mathrm{O}_{2}$ and $f \mathrm{H}_{2} \mathrm{O}$ (or $f \mathrm{CO}_{2}$ ) enables us to characterise the composition of gas phase at depth which is useful information for the interpretation of volcanic gas data. Here also, however, it needs to be stressed that the calculations are heavily dependent upon the accuracy of the solubility models employed to calculate $f \mathrm{H}_{2} \mathrm{O}$ and $f \mathrm{CO}_{2}$. The latter parameter is clearly critical for assessing the pressures of fluid saturation: in this respect, it appears that the $\mathrm{CO}_{2}$ solubility in $\mathrm{K}$ rich basalts is still not appropriately known. This is a research trend which should be given 
the highest priority in the near future for a correct quantitative modeling of volatiles behaviour at Italian volcanoes. Similarly, a full description of degassing processes in shallow magma reservoirs demands that $\mathrm{CO}_{2}$ contents in MI be measured beyond the concentration levels allowed by the FTIR tool. We suggest that future volatile studies implement analytical tools to such an end.

Accepting that our model retrieves $f \mathrm{~S}_{2}$ within the correct order of magnitude then the calculations show that, except in special circumstances, the addition of sulphur does not strongly change pressure estimates with respect to model calculations which consider only $\mathrm{H}_{2} \mathrm{O}$ and $\mathrm{CO}_{2}$ species. As we have seen, this is due to the generally low values of $f \mathrm{~S}_{2}$ calculated at high pressures. Only at low pressure does there exist the possibility that pressures of fluid saturation could be significantly underestimated by neglecting sulphur-bearing species. The Etna example shows that the misfit between the two approaches can be in the order of several hundreds of bars for magmas rich in sulphur.

Our calculations suggest that $f \mathrm{~S}_{2}$ is usually in the range 0.1-1 bar in the most primitive magmas found at Italian volcanoes. Whether this corresponds to environments unusually rich in sulphur relative to other tectonic settings or other arc magmas, remains an open question given the almost total absence of such information for primitive magmas worldwide. We are therefore currently applying our model to mafic magmas erupted in a variety of tectonic environments in an effort to fill this gap. The calculated $f \mathrm{~S}_{2}$ may display dramatic variations during magmatic evolution, however, that seem to depend on open versus closed conduit conditions, as illustrated for Vesuvius. Thus, variations in $f \mathrm{~S}_{2}$ can be potentially used as a sensor to infer the behaviour of magma reservoirs that fed past eruptive events. However, the important variations in $f \mathrm{~S}_{2}$ evidenced in this study conflict with models invoking the control of magma redox state by heterogeneous equilibria between sulphur bearing species dissolved in melt and fluid (e.g., Matthews et al., 1994). In our calculations we assumed that the redox states determined in melt inclusions or whole rocks have remained constant throughout the magmatic evolution of any particular eruptive event. The lack of two-oxide assemblages in most volcanic products prevents us from testing this fundamental assumption and it could be argued that the large variations we calculate in $f \mathrm{~S}_{2}$ correspond in fact to variations in $f \mathrm{O}_{2}$ due to volatile exsolution. The following lines of evidence suggest they are not, however. First, if we suppose that equilibria involving sulphurbearing species control $f \mathrm{O}_{2}$ then we can use eq. (2.1) to evaluate what magnitude of $f \mathrm{O}_{2}$ change is needed in order to maintain relatively constant $f \mathrm{~S}_{2}$ during sulphur exsolution. Suppose a mafic melt with $3000 \mathrm{ppm}$ dissolved sulphur at $\mathrm{NNO}+0.95$ and $1100^{\circ} \mathrm{C}$ with $3 \mathrm{wt} \% \mathrm{H}_{2} \mathrm{O}$ (similar to Stromboli). If it loses $1000 \mathrm{ppm}$ of sulphur while keeping the same $f \mathrm{~S}_{2}$, then equation 10 predicts that $\mathrm{fO}_{2}$ should decrease down to NNO-2.19. While such a reduction during sulphur exsolution is conceivable, it is difficult to reconcile, for instance, with the constant redox state inferred from isotope systematics on pumices at Vesuvius (Marini et al., 1998). Similarly, such a three orders of magnitude drop in $f \mathrm{O}_{2}$ should be accompagnied by strong changes in both phase stabilities and compositions, all of which have gone undetected so far. Second, the detailed thermodynamic analysis of Kilauea volcanic gases has shown that $f \mathrm{O}_{2}$ is unaffected by shallow volatile exsolution (Gerlach, 1993), the collected gases following a cooling trend parallel to NNO, identical to that inferred for the lavas (see also Symonds et al., 1994). Therefore, although we cannot rule out that $\mathrm{fO}_{2}$ varies during volatile exsolution, we believe that such a change is relatively minor compared to that encompassed by $f \mathrm{~S}_{2}$. One possible reason for the relative insensivity of $f \mathrm{O}_{2}$ to the behaviour of sulphur is that water, present in abundance in Italian basalts, is the main controlling species of the magma redox state (via the water dissociation reaction).

The approach we followed in modeling magma degassing needs to be implemented by performing numerical simulations of magma ascent and volatiles exsolution, considering open and closed system behaviours. However, the comparison between our calculations and observed gas compositions suggests that a fluid phase is present at depth, at amounts in the 
order of 4-5 wt $\%$. Although the available data on MI do not allow to prove yet such an hypothesis, it is important to note that if it is true then it will require a significant reevaluation of magma budgets based on volatile emissions (e.g., Allard, 1997; Bruno et al., 2001). Current evaluations have only considered the sulphur or carbon dioxide dissolved in melt as the ultimate source of volcanic degassing. However, consideration of a fluid phase could lead to a significant downsizing of magma volumes required to balance the volatile budget measured at permanently degassing volcanoes such as Etna and Stromboli. To illustrate this point, we take the case of an Etna magma reservoir at 1000 bar with 5 wt\% fluid previously discussed, whose $\mathrm{SO}_{2 \text { tot }}$ content is 1.57 wt $\%$. Allard (1997) calculated that the average $\mathrm{SO}_{2}$ ouptut at Etna for the period 1975-1995 is $1.7 \cdot 10^{6}$ tons/year, whereas the average amount of erupted magmas over the same period is $81 \cdot 10^{6}$ tons/year. By considering only the melt contribution, Allard (1997) calculated that an additional amount of $678 \cdot 10^{6}$ tons/year of magma must be intruded (and not erupted) in order to account for sulphur emissions. In contrast, if a fluid phase is present at 1000 bar, then the $81 \cdot 10^{6}$ tons of magma extruded every year could release $1.27 \cdot 10^{6}$ tons of sulphur or $75 \%$ of the total amount of sulphur emitted, and the need for endogeneous magma degassing at Etna would be much less severe than previously thought.

\section{Acknowledgements}

The paper greatly benefited from constructive reviews by H. Shinoara and R. Moretti.

\section{REFERENCES}

Allard, P. (1997): Endogeneous magma degassing and storage at Mt. Etna, Geophys. Res. Lett., 24, 2219-2222.

Allard, P., J. Carbonnelle, D. Dajlevic, J. Le Bronec, P. Morel, M.C. Robe, J.M. Maurenas, R. FaivrePierret, D. Martin, J.C. Sabroux and P. Zettwoog (1991) : Eruptive and diffuse emissions of $\mathrm{CO}_{2}$ from Mt. Etna, Nature, 351, 387-390.

Allard, P., J. Carbonnelle, N. Métrich, H. Loyer and P. ZetTwoog (1994): Sulphur output and magma de- gassing budget of Stromboli volcano, Nature, 368, 326-329.

Anderson, A.T., S. Newman, S.N. Williams, T.H. Druitt, C. Skirius and E. STOLPER (1989): $\mathrm{H}_{2} \mathrm{O}, \mathrm{CO}_{2}, \mathrm{Cl}$ gas in Plinian and ash-flow Bishop rhyolite, Geology, 17, 221-225.

Armienti, P., F. InNocenti, R. Petrini, M. Pompilio and L. VILLARI (1988): Sub-aphyric alkali basalt from Mt. Etna: inferrences on the depth and composition of the source magma, Rend. Soc. Ital. Mineral. Petrol., 43, 877-891.

Ballhaus, C., R.F. BerRy and D.H. GreEN (1991): High pressure experimental calibration of the olivine-orthopyroxene-spinel oxygen barometer: implications for the oxidation state of the upper mantle, Contrib. Mineral. Petrol., 107, 27-40.

Belkin, H.E., B. De Vivo, K. TöröK and J.D. Webster (1998): Pre-eruptive volatile content, melt inclusion chemistry, and microthermometry of interplinian Vesuvius lavas (pre-A.D. 1631), J. Volcanol. Geotherm. Res., 82, 79-95.

Bertagnini, A., N. Métrich, P. Landi and M. Rosi (2003): Stromboli volcano (Aeolian Archipelago, Italy): an open window on the deep-feeding system of a steady state basaltic volcano, J. Geophys. Res., 108 (B7), 2336, doi:10.1029/2002JB002146.

BonACCORSO, A. (1996): Dynamic inversion of ground deformation data for modelling volcanic sources (Etna 1991-93), Geophys. Res. Lett., 23, 451-454.

BonAcCorso, A. (2001): Mt. Etna volcano: modelling of ground deformation patterns of recent eruptions and considerations on the associated precursors, J. Volcanol. Geotherm. Res., 109, 99-108.

Bruno, N., T. Caltabiano and R. Romano (1999): $\mathrm{SO}_{2}$ emissions at Mt. Etna with particular reference to the period 1993-1995, Bull. Volcanol., 60, 405-411.

Bruno, N., T. Caltabiano, S. Giammanco and R. Romano (2001): Degassing of $\mathrm{SO}_{2}$ and $\mathrm{CO}_{2}$ at Mt. Etna (Sicily) as an indicator of pre-eruptive ascent and shallow emplacement of magma, J. Volcanol. Geotherm. Res., 110, 137-153.

Buchanan, D.L. and J. Nolan (1979): Solubility of sulfur and sulfide immiscibility in synthetic tholeiitic melts and their relevance to Bushveld-complex rocks, Can. Mineral., 17, 483-494.

Capasso, G., S. Inguaggiato and P.M. Nuccio (1994): Chemical variations of the fumarolic gases of La Fossa Vulcano crater, Acta Vulcanol., 3, 173-187.

Capasso, G., W. D'Alessandro, R. Favara, S. InguaggiaTO and F. PARELLO (2001): Interaction between the deep fluids and the shallow groundwaters on Vulcano Island (Italy), J. Volcanol. Geotherm. Res., 108, 187-198.

Caracausi, A., F. Italiano, A. Paonita, A. Rizzo and P. M. NuCCIO (2003): Evidence of deep magma degassing and ascent by geochemistry of peripheral gas emissions at Mt. Etna (Italy): assessment of the magmatic reservoir pressure, J. Geophys. Res., $108(\mathrm{O}), \mathrm{XXXX}$, doi:10.1029/2002JB002095.

Carroll, M.C. and M.J. Rutherford (1987): The stability of igneous anhydrite: experimental results and implications for sulfur behavior in the 1982 El Chichon trachyandesite and other evolved magmas, J. Petrol., 28, 781-801. 
Carroll, M.C. and J.D. Webster (1994): Solubilities of sulfur, noble gases, nitrogen, chlorine and fluorine in magmas, in Volatiles in Magmas, edited by M.R. CARROLL and J.R. HollowAY, Rev. Mineral., 30, 231-279.

Chiodini, G., R. Cioni, L. Marini and C. PAnichi (1995): Origin of the fumarolic fluids of Vulcano Island, Italy and implications for volcanic surveillance, Bull. Volcanol., 57, 99-110.

Cioni, R. (2000): Volatile content and degasssing processes in the A.D. 79 magma chamber at Vesuvius (Italy), Contrib. Mineral. Petrol., 140, 40-54.

Cioni, R., L. Civetta, P. Marianelli, N. MÉtrich, R. SANTACROCE and A. SBRANA (1995): Compositional layering and syn-eruptive mixing of a periodically refilled shallow magma chamber: the A.D. 79 Plinian eruption of Vesuvius, J. Petrol., 36, 739-776.

Cioni, R., P. Marianelli and R. Santacroce (1998): Thermal and compositional evolution of the shallow magma chambers of Vesuvius: evidence from pyroxene phenocrysts and melt inclusions, J. Geophys. Res., 103, 18277-18294.

Civetta, L. and R. SAntacroce (1992): Steady state magma supply in the last 3400 years of Vesuvius activity, Acta Vulcanol., 2, 147-159.

CivetTa, L., R. Galati and R. SANTACroce (1991): Magma mixing and convective compositional layering within the Vesuvius magma chamber, Bull. Volcanol., 53, 287-300.

Clemente, B., B. Scaillet and M. Pichavant (2004): The solubility of sulphur in hydrous rhyolitic melts, $J$. Petrol., 45, 2171-2196.

Clocchiatti, R.A. and N. MÉtrich (1984): Témoignages de la contamination dans les produits des éruptions explosives des M. Silvestri (1892) et M. Rossi (1669) (Mt. Etna), Bull. Volcanol., 47, 909-928.

Clocchiatti, R.A., J. Weisz, M. Mosbah and J.C. Tanguy (1992): Coexistence de verres alcalins et tholéiitiques saturés en $\mathrm{CO}_{2}$ dans les olivines des hyaloclastites d'Aci Castello (Etna, Sicile, Italie). Arguments en faveur d'un manteau anormal et d'un réservoir profond, Acta Vulcanol., 2, 161-173.

Clocchiatti, R., A. Gioncada, M. Mosbah and A. Sbrana (1994a): Possible deep origin of sulfur output at Vulcano (Southern Italy) in the light of melt inclusion studies, Acta Vulcanol., 5, 49-53.

Clocchiatti, R., A. Del Moro, A. Gioncada, J.L. Joron, M. Mosbah, L. Pinarelli and A. Sbrana (1994b): Assessment of a shallow magmatic system: the 18881890 eruption, Vulcano Island, Italy, Bull. Volcanol., 56, 466-486.

Di Carlo, I., M. Pichavant, S. Rotolo and B. Scaillet (2004): Ascent of Stromboli yellow pumice magmas: experimental simulation at $P<=4 \mathrm{~kb}$, Geophys. Res. Abstr., 6, 04122

Di Liberto, V., P.M. Nuccio and A. PAonita (2002): Genesis of chlorine and sulphur in fumareloc emissions at Vulcano Island (Italy): assessment of $p H$ and redox conditions in the hydrothermal system, J. Volcanol. Geotherm. Res., 116, 137-150.

Diliberto, I.S., S. GuRRIERI and M. VAlenZA (2002): Relationships between diffuse $\mathrm{CO}_{2}$ emissions and volcanic activity on the Island of Vulcano (Aeolian Islands, Italy) during the period 1984-1994, Bull. Volcanol., 64, 219-228
Dixon, J.E. (1997): Degassing of alkalic basalts, Am. Mineral., 82, 368-378.

Dixon, J.E., E.M. StolPeR and J.R. Holloway (1995): An experimental study of water and carbon dioxide solubilities in mid-ocean ridge basaltic liquids, Part I. Calibration and solubility models, J. Petrol., 36, 1607-1631.

FERRY, J.M. and L. BAUMGARTNER (1987): Thermodynamic models of molecular fluids at the elevated pressures and temperatures of crustal metamorphism, in Thermodynamic Modelling of Geological Materials: Minerals, Fluids and Melts, edited by I.S.E. CARMICHAEL and H.P. EugSTER, Rev. Mineral., 17, 323-365.

FLowers, G.C. (1979): Correction of Holloway's (1977) adaptation of the modified Redlich-Kwong equation of state for calculation of the fugacities of molecular species in supercritical fluids of geologic interest, Contrib. Mineral. Petrol., 69, 315-18.

Francalanci, L., P. Manetti and A. Peccerillo (1989): Volcanological and magmatological evolution of Stromboli volcano (Aeolian Islands): the roles of fractional crystallization, magma mixing, crustal contamination and source heterogeneity, Bull. Volcanol., 51, 355-378.

Freda, C., M. Gaeta, D.M. Palladino and R. Trigila (1997): The Villa Senni eruption (Alban Hills, Central Italy): the role of $\mathrm{H}_{2} \mathrm{O}$ and $\mathrm{CO}_{2}$ on the magma chamber evolution and on the eruptive scenario, J. Volcanol. Geotherm. Res., 78, 103-120.

Frezzotti, M.L., B. De Vivo and R. Clocchiatti (1991): Melt-mineral-fluid interactions in ultramafic nodules from alkaline lavas of Mt. Etna (Sicily, Italy): melt and fluid inclusion evidence, J. Volcanol. Geotherm. Res., 47, 209-219.

Froese, E. and A.E. GunTER (1976): A note on the pyrrhotitesulfur vapor equilibrium, Econ. Geol., 71, 1589-1594.

GERLACH, T.M. (1980): Evaluation and restoration of the 1970 volcanic gas analyses from Mt. Etna, Sicily, $J$. Volcanol. Geotherm. Res., 6, 165-178.

GERLACH, T.M. (1993): Oxygen buffering of Kilauea volcanic gases and the oxygen fugacity of Kilauea basalt, Geochim. Cosmochim. Acta, 57, 795-814.

Giggenbach, W.F., D. Tedesco, Y. Sulistiyo, A. Caprai, R. Cioni, R. FAVAra, T.P. Fischer, J.I. Hirabayashi, M. Korzhinsky, M. Martini, I. Menyailov and H. SHINOARA (2001): Evaluation of results from the fourth and fifth IAVCEI field workshops on volcanic gases, Vulcano Island, Italy and Java, Indonesia, J. Volcanol. Geotherm. Res., 108, 157-172.

Gioncada, A., R. Clocchiatti, A. Sbrana, P. Bottazzi, D. MAssare and L. OtTOLINI (1998): A study of melt inclusions at Vulcano (Aeolian Islands, Italy): insigths on the primitive magmas and on the volcanic feeding system, Bull. Volcanol., 60, 286-306.

HarRis, A.J.L. and D.S. Stevenson (1997): Magma budgets and steady-state activity of Vulcano and Stromboli, Geophys. Res. Lett., 24, 1043-1046.

Haughton, D.R., P.L. Roeder and B.J. Skinner (1974): Solubility of sulfur in mafic magmas, Econom. Geol., 69, 451-467.

HollowAY, J.R. (1977): Fugacity and activity of molecular species in supercritical fluids, in Thermodynamics in Geology, edited by D. Frase (Dordrecht: Reidel Publishing Company), 161-81. 
Holloway, J.R. and J. Blank (1994): Applications of experimental results to $\mathrm{C}-\mathrm{O}-\mathrm{H}$ species in natural melts, in Volatiles in Magmas, edited by M.R. CARROLL and J.R. Holloway, Rev. Mineral., 30, 187-230.

Huntingdon, A.T. (1973): The collection of volcanic gases from Mt. Etna, Phil. Trans. R. Soc. London, 274, 119128.

Kamenetsky, V. and R. Clocchiatti (1996): Primitive magmatism of Mt. Etna: insights from mineralogy and melt inclusions, Earth Planet. Sci Lett., 142, 553-572.

KATSURA, T. and S. NAGASHIMA (1974): Solubility of sulfur in some magmas at 1 atmosphere, Geochim. Cosmochim. Acta, 38, 517-531.

KILINC, A., I.S.E. CARMICHAEL, M.L. RIVERS and R.O. SACKS (1984): The ferric-ferrous ratio of natural silicate liquids equilibrated in air, Contrib. Mineral. Petrol., 83, 136140.

LimA, A., H.764E. BeLKIN and K. TÖRÖK (1999): Understanding Vesuvius magmatic processes: evidence from primitive silicate-melt inclusions in medieval scoria clino-pyroxenes (Terzigno Formation), Mineral. Petrol., 65, 185-206.

LuHR, J.F. (1990): Experimental phase relations of waterand sulfur-saturated arc magmas and the 1982 eruptions of El Chichòn volcano, J. Petrol., 31, 1071-1114.

Marianelli, P., N. Métrich, R. Santacroce and A. Sbrana (1995): Mafic magma batches at Vesuvius: a glass inclusion approach to the modalities of feeding stratovolcanoes, Contrib. Mineral. Petrol., 120, 159-169.

Marianelli, P., N. Métrich and A. SBrana (1999): Shallow and deep reservoirs involved in magma supply of the 1944 eruption of Vesuvius, Bull. Volcanol., 61, 48-63.

Marini, L., V. Chiappini, R. Cioni, G. Cortecci, E. DinelLi, C. Principe and G. Ferrara (1998): Effect of degassing on sulfur contents of $\delta^{34} \mathrm{~S}$ values in SommaVesuvius magmas, Bull. Volcanol., 60, 187-194.

Matthews, S.J., A.P. Jones and A.D. BeARD (1994): Buffering of melt oxygen fugacity by sulphur redox reactions in calc-alkaline magmas, J. Geol. Soc. London, 151, 815-23.

Mavrogenes, J. and H.S.C. O'NeILl (1999): The relative effects of pressure, temperature and oxygen fugacity on the solubility of sulfide in mafic magmas, Geochim. Cosmochim. Acta, 63, 1173-1180.

MÉTRICH, N. (1990): Chlorine and fluorine in tholeiitic and alkaline lavas of Etna (Sicily), J. Volcanol. Geotherm. Res., 40, 133-148.

Métrich, N. and R. ClocChiatti (1989): Melt inclusion investigation of the volatile behaviour in historic alkali basaltic magmas of Etna, Bull. Volcanol., 51, 185-198.

MÉtrich, N. and R. ClocChiatti (1996): Sulfur abundance and its speciation in oxidized alkaline melts, Geochim. Cosmochim. Acta, 60, 4151-4160.

MÉTRICH, N. and M. MosbaH (1988): Détermination des teneurs en carbone de quelques verres basaltiques; analyses par réactions nucléaires, Bull. Mineral., 111, 511-522.

MÉTRICH, N. and M.J. RUTHERFORD (1998): Low pressure crystallization paths of $\mathrm{H}_{2} \mathrm{O}$-saturated basaltic-hawaiitic melts from Mt. Etna: implications for open-system degassing of basaltic volcanoes, Geochim. Cosmochim. Acta, 62, 1195-1205.

Métrich, N., R. Clocchiatti, M. Mosbah and M. ChausSIDON (1993): The 1989-1990 activity of Etna magma mingling and ascent of $\mathrm{H}_{2} \mathrm{O}-\mathrm{Cl}-\mathrm{S}$-rich basaltic magma. Evidence from melt inclusions, J. Volcanol. Geotherm. Res., 59, 131-144.

MÉtrich, N., A. Bertagnini, P. LANDi and M. Rosi (2001): Crystallisation driven by decompression and water loss at Stromboli volcano (Aeolian Islands, Italy), J. Petrol., 42, 1471-1490.

Métrich, N., M. Bonnin-Mosbah, J. Susini, B. Menez and L. GALOISY (2002): Presence of sulfite $\left(S^{I V}\right)$ in arc magma: implications for volcanic sulfur emissions, Geophys. Res. Lett., 29, 10.1029/2001GL014607.

Moretti, R., P. PAPAle and G. OtTONELlo (2003): A model for the saturation of C-O-H-S fluids in silicate melts, in Volcanic Degassing, edited by C. OPPENHEIMER, D.M. Pyle and J. BARCLAY, Geol.Soc.Spec. Publ. 213, 81-101.

Murru, M., C. Montuori, M. Wyss and E. Privitera (1999): The location of magma chambers at Mt. Etna, Italy, mapped by $b$-values, Geophys. Res. Lett., 26, 2553-2556.

Nuccio, P.M. and A. PAONITA (2001): Magmatic degassing of multicomponent vapors and assessment of magma depth: application to Vulcano Island (Italy), Earth Planet. Sci. Lett., 193, 467-481.

Nuccio, P.M., A. PAOnita and F. Sortino (1999): Geochemical modelling of mixing between magmatic and hydrothermal gases: the case of Vulcano Island, Italy, Earth Planet. Sci. Lett., 167, 321-333.

O'NEILL, H.St. and J.A. MAVROGENES (2002): The sulfide capacity and the sulfur content at sulfide saturation of silicate melts at $1400^{\circ} \mathrm{C}$ and 1 bar, J. Petrol., 43, 1049-1087.

Paonita, A., R. Favara, P.M. Nuccio and F. Sortino (2002): Genesis of fumarolic emissions as inferred by isotope mass balances: $\mathrm{CO}_{2}$ and water at Vulcano Island, Italy, Geochim. Cosmochim. Acta, 66, 759-772.

PAPAlE, P. (1997): Thermodynamic modelling of the solubility of a one-component $\mathrm{H}_{2} \mathrm{O}$ or $\mathrm{CO}_{2}$ fluid in silicate liquids, Contrib. Mineral. Petrol., 126, 237-251.

RaiA, F., J.D. Webster and B. De Vivo (2000): Pre-eruptive volatile contents of Vesuvius magmas: constraints on eruptive history and behavior, I. The medieval and modern interplinian activities, Eur. J. Mineral., 12, 179-193.

Roggensack, K., R.L. Hervig, S.B. McKnight and S.N. WiLliams (1997): Explosive basaltic volcanism from Cerro Negro volcano: influence of volatiles on eruptive style, Science, 277, 1639-1642.

Sato, M. and J.G. Moore (1973): Oxygen and sulfur fugacities of magmatic gases directly measured in active vents of Mt. Etna, Philos. Trans. R. Soc. London, Ser. A, 274, 137-146.

SAXENA, S.K. and Y. FeI (1987): High pressure and high temperature fluid fugacities, Geochim. Cosmochim. Acta, 51, 783-791.

Scaillet, B. and B.W. Evans (1999): The June 15, 1991 eruption of Mt. Pinatubo. I. Phase equilibria and preeruption $P-T-f \mathrm{O}_{2}-f \mathrm{H}_{2} \mathrm{O}$ conditions of the dacite magma, J. Petrol., 40, 381-411.

SCAILlet, B. and M. Pichavant (2003): Experimental constraints on volatile abundances in arc magmas and their implications for degassing processes, in Volcanic Degassing, edited by C. OPPENHEIMER, D.M. PYLE and J. Barclay, Geol. Soc. Spec. Publ. 213, 23-52.

Scaillet, B., Clemente, B.W. Evans and M. Pichavant 
(1998): Redox control of sulfur degassing in silicic magmas, J. Geophys. Res., 103, 23937-23949.

SHI, P. and S.K. SAXENA (1992): Thermodynamic modeling of the C-O-H-S fluid system, Am. Mineral., 77, 1038-1049.

Signorelli, S. and B. CAPACCIONI (1999): Behaviour of chlorine prior and during the 79 A.D. Plinian eruption of Vesuvius (Southern Italy) as inferred from the present distribution in glassy mesostases and whole-pumices, Lithos, 46, 715-730.

Signorelli, S, G. Vagelli and C. Romano (1999): Preeruptive volatile $\left(\mathrm{H}_{2} \mathrm{O}, \mathrm{F}, \mathrm{Cl}\right.$ and $\left.\mathrm{S}\right)$ contents of phonolitic magmas feeding the 3550-year old Avellino eruption from Vesuvius, Southern Italy, J. Volcanol. Geotherm. Res., 93, 237-256.

Sobolev, A.V., V.S. Kamenetsky, N. Métrich, R. ClocChIATti, N.N. Kononkova, A.L. DevirTs and V.I. Ustinov (1991): Volatile regime and crystallisation conditions in Etna Hawaiite lavas, Geochimica, 9, 1277-1290.

Symonds, R.B., W.I. Rose, G.J.S. BluTH and T.M. GerLaCH (1994): Volcanic gas studies: methods, results, and applications, in Volatiles in Magmas, edited by M.R. CARROLL and J.R. Holloway, Rev. Mineral., 30, 1-60.

Symonds, R.B., T.M. GERLACH and M.H. ReED (2001): Magmatic gas scrubbing: implications for volcano monitoring, J. Volcanol. Geotherm. Res., 108, 303-341.

Tanguy, J.C., M. Condomines and G. KiefFer (1997): Evolution of the Mt. Etna magma: constraints on the present feeding system and eruptive mechanism, $J$. Volcanol. Geotherm. Res., 75, 221-250.

Todesco, M. (1997): Origin of fumarolic fluids at Vulcano (Italy). Insights from isotope data and numerical modeling of hydrothermal circulation, J. Volcanol. Geotherm. Res., 79, 63-85.
Trigila, R. and A.A. De Benedetti (1993): Petrogenesis of Vesuvius historical lavas constrained by Pearce element ratios analysis and experimental phase equilibria, J. Volcanol. Geotherm. Res., 58, 315-343.

Trigila, R., F.J. Spera and C. Aurisicchio (1990): The 1983 Mt. Etna eruption: thermochemical and dynamical inferences, Contrib. Mineral. Petrol., 104, 594-608.

Vagelli, G., H.E. Belkin, B. De Vivo and R. Trigila (1992): Silicate-melt inclusions in recent Vesuvius lavas (A.D. 1631-1944), I. Petrography and microthermometry, Eur. J. Mineral., 4, 1113-1124.

Vagelli, G., B. De Vivo and R. Trigila (1993): Silicatemelt inclusions in recent Vesuvius lavas (A.D. 16311944), II. Analytical chemistry, J. Volcanol. Geotherm. Res., 58, 367-376.

Vergniolle, S. and C. Jaupart (1986): Separated twophase flow and basaltic eruptions, J. Geophys. Res., 91, 12842-12860.

Wallace, P.J. and I.S.E. Carmichael (1992): Sulfur in basaltic magmas, Geochim. Cosmochim. Acta, 56, 1683-1874.

Webster, J.D. and B. De Vivo (2002): Experimental and modeled solubilities of chlorine in aluminosilicate melts, consequences of magma evolution, and implications for exsolution of hydrous chloride melt at Mt. Somma-Vesuvius, Am. Mineral., 87, 1046-1061.

Webster, J.D., F. Raia, B. De Vivo and G. Rolandi (2001): The behavior of chlorine and sulfur during differentiation of the Mt. Somma-Vesuvius magmatic system, Mineral. Petrol., 73, 177-200.

ZHANG, Y. (1999): $\mathrm{H}_{2} \mathrm{O}$ in rhyolitic glasses and melts: measurement, speciation, solubility, and diffusion, Rev. Geophys., 37, 493-516. 